UNIVERSIDADE DE SÃO PAULO

FACULDADE DE FILOSOFIA, LETRAS E CIÊNCIAS HUMANAS

DEPARTAMENTO DE LETRAS CLÁSSICAS E VERNÁCULAS

PROGRAMA DE PÓS-GraduAÇÃo EM FILOLOGIA E LÍNGUA PoRTUGUESA

RENATA BARBOSA VICENTE

MudanÇa Gramatical da Palavra afinal e SUA

GRAMATICALIZAÇÃo NUM CONTRASTE ENTRE

VARIEDADES LINGUÍSTICAS:

- Português do Brasil e de Portugal -

São Paulo

Maio / 2009 


\section{Mudança Gramatical da Palavra afinal e SUA GRAMATICALIZAÇÃO NUM CONTRASTE ENTRE VARIEDADES LINGUÍSTICAS: - Português do Brasil e de Portugal -}

Dissertação de Mestrado apresentada ao Programa de Pós-graduação em Filologia e Língua Portuguesa, do Departamento de Letras Clássicas e Vernáculas, da Faculdade de Filosofia, Letras e Ciências Humanas da Universidade de São Paulo, como requisito parcial para a obtenção do título de Mestre em Filologia e Língua Portuguesa.

Orientadora: Prof ${ }^{\mathrm{a}}$. Dra. Maria Célia LimaHernandes

São Paulo

Maio / 2009 
Banca Examinadora:

Prof ${ }^{a}$ Dra. Maria Célia Lima-Hernandes (orientadora-USP)

Prof ${ }^{\text {a }}$ Dra. Mariângela Rios de Oliveira ( UFF)

Prof a Dra. Anna Christina Bentes (IEL/UNICAMP) 


\section{Dedicatória}

Dedico a

Deus,

Décio,

Isa, Antonio, Paula

e Cecília. 


\section{AGRADECIMENTOS}

A Deus, que sempre me deu forças para continuar na trajetória árdua da pesquisa, livrando-me dos maus rumores, que muitas vezes cercam o ser humano e lançam-no à lama.

À minha orientadora, Profa. Dra. Maria Célia Pereira Lima-Hernandes, pela competência profissional capaz de ampliar a formação do ser humano e pela confiança que muitas vezes se apresentou em grandes doses de estímulos, em meios as minhas inseguranças.

À Prof ${ }^{a}$ Dra. Anna Christina Bentes e à Prof ${ }^{a}$ Dra. Mariângela Rios de Oliveira, que contribuíram para o desenvolvimento deste trabalho, abordando pontos fundamentais da pesquisa e manifestando sugestões que permitiram a ampliação do meu conhecimento.

Ao Décio, meu marido, que todas as vezes compreendeu a minha ausência em dias e madrugadas, bem como pela disposição em estar me acompanhando nas minhas empreitadas.

À minha mãe que, com seu espírito de mulher guerreira, me ensinou a ir buscar, lutar e jamais desistir dos meus sonhos.

Ao meu pai que sempre me ensinou o caminho honesto e humilde da vida, fazendo-me entender que muitas vezes para alcançar um objetivo é necessário refletir sobre as ações e até se redimir das atitudes impulsivas que me levavam ao desespero.

À minha querida irmã, Paula, que com seu jeito manso e suave de falar sempre me provou quão importante é manter a calma nos momentos de ansiedade.

À Cecília Naumovs Florentino pela discrição, paciência, compreensão, apoio e parceria incondicional.

À Lídia Spaziani pelo abstract. 
À Cristina Lopomo Defendi e Kelly Viviane Bernardo pela participação na aplicação dos testes e diálogos.

À minha amiga, Luciana de Oliveira Terra, com quem pude dividir risos e contar com o apoio profissional.

Aos amigos e professores do Centro Universitário Fundação Santo André, cuja menção aos nomes seria inviável e injusto, uma vez que poderia incorrer no erro de deixar de citar algum. Sei que muitos torceram pela minha caminhada.

Ao Bento, que me acompanhou nas noites frias aquecendo meus pés enquanto trabalhava e que, muitas vezes, ainda que irracionalmente, cobrava-me beijos e carinhos. 
"Saber uma gramática não significa saber de cor algumas regras que se aprendem na escola, ou saber algumas análises morfológicas e sintáticas. Mais profundo do que esse conhecimento é o conhecimento (intuitivo ou inconsciente) necessário para falar efetivamente a língua. (...)”

( Sírio Possenti ) 


\section{Lista de quadros}

Quadro 1 Acepções de dicionários................................................................ p. 51

Quadro 2 Resumo dos Padrões funcionais..................................................... p. 66

Quadro 3 Resumo do número de dados analisados do século XVII ao XX.... p. 76

Quadro 4 Resultado do teste 2 sobre a classificação gramatical da palavra afinal ........................................................................... p. 93

Quadro 5 Resultado do teste 2 sobre a classificação gramatical da palavra $a$ final.............................................................................. p. 94 


\section{Sumário}

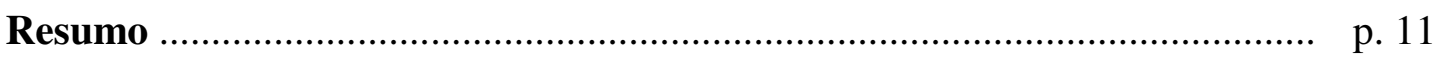

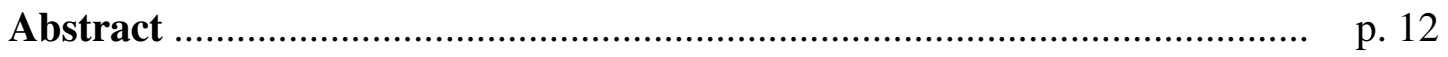

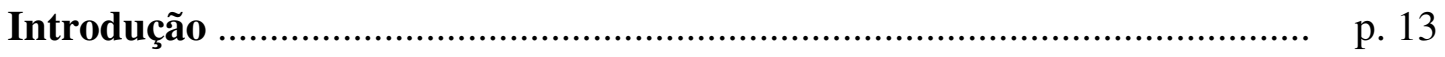

Capítulo I : Fundamentação teórica........................................................ p. 20

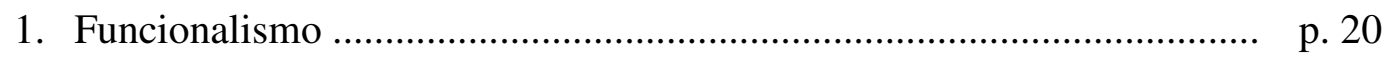

2. A Gramaticalização numa perspectiva funcionalista............................. p. 22

3. Princípio da Unidirecionalidade ......................................................... p. 26

4. Modelos associados à Gramaticalização como método de análise.......... p. 29

4.1 O modelo proposto por Hopper............................................. p. p. 29

4.2 O modelo proposto por Castilho............................................ p. 31

Capítulo II: Aspectos Metodológicos....................................................... p. 33

1. Uma hipótese de mudança e a elaboração de um estudo-piloto.............. p. 33

Capítulo III: afinal no Português............................................................ p. 45

1. Incursão em dicionários.................................................................. p. 45

2. Incursão em gramáticas e internet .................................................... p. 52

3. Comportamento funcional: identificando os padrões funcionais............ p. 57

Capítulo IV: Estudo comparativo de AFINAL nas variedades PB e PP...... p. 69

1. Padrões funcionais da palavra afinal no PP........................................ p. 69

2. Padrões funcionais da palavra afinal no PB...................................... p. 73

3. Contraste entre variedades............................................................. p. 76

Capítulo V: Proposta de diálogo com o ensino........................................ p. 82

1. A situação do livro didático............................................................ p. 83 
2. Um teste sobre os usos e reconhecimento de funções........................... p. 88

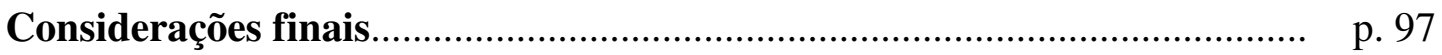

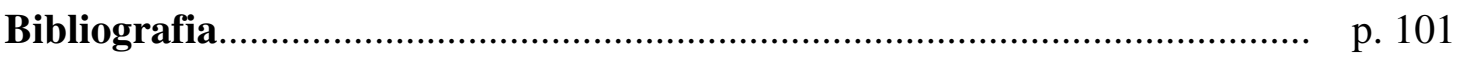

Referências Bibliográficas........................................................................... p. 101

Referências virtuais da Internet.................................................................... p. 104 


\section{Resumo}

Este trabalho apresenta um estudo sobre a mudança gramatical que tem afetado a palavra afinal. Para isso, iniciamos nossas buscas em dicionários sincrônicos e etimológicos, que favoreceram reconhecer a ampliação do espectro funcional desse item; em seguida, coletamos dados da língua falada e, em face do pouco número de ocorrências, partimos para dados da língua escrita. Norteados pela fundamentação teórica que deriva de Heine, Claudi \& Hünnemeyer (1991), reconhecemos um percurso unidirecional seguido pelo item afinal, bem como pudemos reconhecer alguns padrões funcionais associados aos usos desse item. Também, verificamos que as rotas percorridas pelo encadeamento dos padrões funcionais podem assumir um movimento tanto da esquerda para a direita - resultando em gramaticalização; quanto da direita para a esquerda resultando em lexicalização.

PALAVRAS-CHAVE: advérbio; funcionalismo; gramaticalização; unidirecionalidade; lexicalização. 


\begin{abstract}
This research presents a study on the grammatical change that has been affecting the word "afinal". For this we initiate our searches in synchronous and etymologic dictionaries; that has promoted to recognize the enlargement of the functional spectrum of this item. After that, we collected data from the spoken language and, in face of the scarce number of occurrences; we decided to deal with the written language. Guided by the theoretical basis that derives from Heine, Claudi \& Hünnemeyer (1991), we recognize a unidirectional way, followed by the item "AFINAL", as well as we could recognize some functional standards associated to the use of this item. We also, verify that the routes covered by the functional standards chaining may assume a movement from the left to the right - resulting in grammaticalization, and also from the right for the left, resulting in lexicalization.
\end{abstract}

Keywords: adverb; functionalism; grammaticalization, unidirecionality; lexicalization. 


\section{Introdução}

Os primeiros passos desta pesquisa iniciaram-se durante o curso de pósgraduação desenvolvido na USP, quando tivemos a oportunidade de cursar a disciplina: “A interface Sociolinguistica/Gramaticalização - fenômenos em mudança no Português", ainda antes de ingressar no mestrado, na condição de "aluno especial". Nessa ocasião, motivou-nos o reconhecimento de que o processo de gramaticalização também pudesse atuar nas alterações que percebíamos ocorrer com o item afinal.

As leituras bibliográficas e as discussões realizadas no curso, não só sobre o item afinal, mas também sobre outros objetos pesquisados por alguns colegas, permitiram-nos aguçar a intuição e iniciar nossas reflexões sobre o processo de gramaticalização a que a palavra afinal 'parecia' - até então tratavam-se de hipóteses estar sujeita.

No decorrer dos estudos e em face de algumas análises que foram sendo desenvolvidas, em primeiro plano, para apresentações em congressos e seminários, e em segundo, para um estudo-piloto, tivemos oportunidade de aprofundar as reflexões e de perceber a importância do objeto para a compreensão da mudança gramatical no português.

Nesse passo, estando certos de nossos ideais de pesquisa, decidimos tomar por objetivo precípuo apresentar um estudo sobre a mudança gramatical que teria afetado a palavra afinal. Para isso, iniciamos nossas buscas em dicionários tanto sincrônicos quanto etimológicos. 
Ainda nessa fase, percebemos que, para o desenvolvimento de uma investigação a respeito do item, seria necessário também entender o que se passava com os itens fim e final, já que estes se apresentavam remissivos ao termo afinal no material que consultamos. O próximo passo foi recorrer às gramáticas normativas, cujas informações relativas ao termo eram apresentadas de forma reduzida e, até mesmo, inexistiam em alguns materiais bibliográficos. Essas constatações nos levaram a uma incursão pela internet, já que o espaço virtual contém um número abrangente de dados do português registrados e também uma variedade interessante de tipos de texto.

Nessa empreitada, tomamos contato, ao contrário do que esperávamos, com explicações espelhadas nas orientações normativistas, mas que contribuíam para uma reflexão mais profunda sobre o fato: argumentos desnudados de elementos factuais poderiam servir de provas incontestáveis de que a palavra afinal deveria ser de determinada forma empregado? Essa discussão é tecida nesta dissertação.

No passo seguinte da pesquisa, preocupamo-nos com o corpus. Para dar conta desse quesito, reunimos algumas amostras de caráter diversificado. A primeira delas derivou do Corpus constituído originariamente por Tarallo com a finalidade de ensinar linguística histórica a seus alunos. Esse material era representado por documentos históricos do século XIII ao XX.

No que se refere a essa seleção de textos feita por Tarallo, alguns problemas foram apontados por vários pesquisadores que estudaram fenômenos linguísticos presentes no material. Alguns dos problemas apontados foram os seguintes: (a) o de que, em alguns séculos, havia documentos de fonte não fidedigna; (b) o de que houve a inclusão de documentos do português de Portugal sem o devido esclarecimento; e (c) o 
de haver em determinados períodos o excesso de textos exclusivamente literários. Essas foram as razões que nos levaram a utilizar documentos somente dos séculos XIII ao XVI, em que esses problemas não ocorrem.

Tendo em vista a ausência de ocorrências mesmo nesse material criteriosamente selecionado, passamos à constituição de nova amostra de modalidade falada a partir do corpus PEUL e, depois disso, do corpus NURC, ambos relativos à cidade do Rio de Janeiro.

Posteriormente, com o fim de atender às necessidades do projeto em que se insere esta pesquisa, qual seja, o Projeto História do Português Paulista, fizemos nova incursão em materiais do NURC, desta vez relativo a São Paulo. Também consultamos a amostra do PHPP (Projeto História do Português Paulistano), formada por entrevistas com falantes cultos de São Paulo, gravadas em sua maioria no ano de 2007.

Diante dos dados levantados, apesar do baixo número de ocorrência, foi possível analisar o comportamento do item na modalidade de língua falada, bem como perceber como o item se comporta na variedade popular e culta.

Esse foi um forte indício de que abordar critérios sociolinguísticos seria necessário durante a pesquisa. Hipotetizamos, inicialmente, que quanto mais erudito é o item-fonte menos sujeito ao processo de gramaticalização estaria, porque não seria muito produtivo em situações de comunicação espontânea. Entretanto, uma vez ocorrendo essa gramaticalização, o processo deveria assumir uma velocidade mais lenta. 
Exatamente por esse processo de gramaticalização lento é que para compreender o que aconteceu com o item sob análise foi necessário recorrer a séculos anteriores, com vistas à implementação de um estudo diacrônico.

Embora já tivéssemos consultado o corpus do Tarallo, do período XIII ao XVI, e não houvéssemos encontrado dados, tínhamos a datação do dicionário etimológico de Cunha (1986) situada no século XVIII.

Apesar das dificuldades especialmente marcadas pela ausência de uma lista robusta de dados, apesar das seguidas tentativas de colecioná-los, e do que essa ausência de dados poderia estar nos dizendo sobre o item no português, insistimos numa nova incursão. Dessa vez, constituímos uma amostra de língua escrita a partir do corpus do Português (para analisar dados do português de Portugal em constraste com o do Brasil), referente ao período do século XIV ao XX.

Dada a agilidade da ferramenta de busca no material, utilizamos o corpus digitalizado por Mark Davies e Michael Ferreira (2006): Corpus do Português ${ }^{1}$ (45 milhões de palavras, sécs. XIV-XX). Nesse material, conseguimos exemplos de ocorrências que ilustravam sua datação etimológica, uma vez que só encontramos dados a partir do século XVIII.

\footnotetext{
${ }^{1}$ Trata-se de um corpus totalmente digitalizado, o que contribui muito para acesso aos dados, disponível em http://www.corpusdoportugues.org. Ele possui aproximadamente 45 milhões de palavras do português e destina-se a todos os estudiosos da língua que queiram confirmar suas hipóteses. Este corpus inclui extratos de texto eletrônicos de edições do Público e da Folha, jornal diário português de grande circulação em Portugal e Brasil, respectivamente, também inclui obras literárias tanto de autores portugueses como de brasileiros.
} 
Com vistas a uma tentativa de responder a questionamentos apresentados em forma de objetivos, hipotetizamos que:

a) se o item afinal está sujeito à mudança, é provável que reconheçamos diferentes padrões funcionais;

b) na modalidade falada, apesar do baixo número de ocorrências, seja possível reconhecer as alterações de padrões funcionais, os quais podem ser ratificados ou ampliados na modalidade escrita, onde há um número de dados mais representativo;

c) se estivermos lidando com um item erudito, o item revele baixo grau de gramaticalização;

d) além de estar sujeito à gramaticalização, o item afinal também pode estar sujeito à lexicalização;

e) apesar de o item ser empregado nas variedades do PB e do PP, é plausível que o item se comporte diferentemente nas duas línguas.

f) é possível traçar um diálogo sobre o fenômeno com o ensino de Língua Portuguesa.

Reunidos os dados das amostras, procedemos às análises com os seguintes objetivos:

a) identificar os padrões funcionais que envolvem o item afinal;

b) explicar as possíveis alterações de padrões nas modalidades falada e escrita; 
c) explanar o comportamento funcional do item sob análise nas variedades popular e culta;

d) verificar se o item sob análise estaria sujeito à gramaticalização ou à lexicalização;

e) analisar se o item afinal apresenta comportamento funcional diferenciado entre o Português Brasileiro (PB) e o Português de Portugal (PP).

f) elaborar uma proposta de diálogo entre o estudo do fenômeno com o ensino de Língua Portuguesa.

Com vistas a responder aos questionamentos anteriormente explicitados e a validar as hipóteses formuladas, organizamos esta dissertação em cinco capítulos.

No primeiro capítulo, apresentamos as bases funcionalistas que orientarão o estudo da gramaticalização, também definida e explanada em seus pressupostos nesse mesmo capítulo.

No segundo capítulo, procedemos a um estudo pontual do objeto delimitado como alvo de estudo - a palavra afinal. Para isso, consultamos gramáticas, manuais, dicionários sincrônicos e etimológicos. Esses elementos serão fundamentais para a compreensão das orientações (nem sempre claras) que recorrem em manuais e consultórios gramaticais. Também apresentamos elementos recuperados do estudopiloto desenvolvido previamente. Esse estudo forneceu informações preciosas que facilitarão a tarefa de organização dos padrões funcionais. 
No capítulo terceiro, apresentamos informações de caráter metodológico, envolvendo as amostras e os tratamentos propostos dos dados. Exatamente nesse capítulo fazemos o reconhecimento dos padrões funcionais do item estudado (afinal).

No capítulo 4, procedo à analise dos dados com vistas a verificar as semelhanças e diferenças da palavra afinal na variedade do Português de Portugal (PP) e Português do Brasil (PB). Além dos dados contemporâneos analisados na amostra que compôs o corpus de nossa pesquisa, representados pelo século $\mathrm{XX}$, também foi importante recorrermos a séculos anteriores, do período do XVII ao XIX, pois melhor poderíamos confirmar nossas explicações.

Dedicamos o capítulo 5 a uma proposta de diálogo entre gramaticalização e o ensino. Para desempenhar essa proposta levantamos materiais didáticos e aplicamos dois testes em informantes que cursavam uma disciplina de pós-graduação e (a maioria) tinha experiência de magistério. Este material permitiu-nos apoiar explicações sobre gramaticalização. Por fim, nas considerações finais, apresentamos as conclusões a que chegamos com nossa pesquisa. 


\section{Capítulo I: FUNDAMENTAÇÃO TEÓRICA}

\section{O Funcionalismo}

Para melhor compreendermos a corrente funcionalista, acreditamos ser importante apresentar o ponto de vista funcional de alguns linguistas. Assim, iniciemos por Thompson, Hopper e Givón que passaram a defender uma linguística baseada no uso, cuja tendência é analisar a língua sem perder de vista o contexto extralinguístico e situacional.

Com base nessa concepção, a sintaxe é uma estrutura em processo de mudança em virtude das estratégias de organização da informação empregadas pelos falantes no momento da interação discursiva (MARTELOTTA e AREAS, 2003:23).

Semelhantemente, Neves (2004) define a gramática funcional como uma teoria que trata da organização gramatical das línguas naturais cujo objetivo é integrar-se em uma teoria global da interação social. Segundo essa autora, a gramática funcional leva em consideração o uso das expressões linguísticas na interação verbal, o que supõe de antemão uma relação pragmática do componente sintático-semântico e a relação entre eles.

Para Mackenzie (1992, apud NEVES, 2004), a gramática funcional visa a explicar regularidades dentro das línguas e através delas, em termos de aspectos recorrentes das circunstâncias sob as quais as pessoas usam a língua. 
Segundo Dik (1997, apud LIMA-HERNANDES, 2005) a gramática funcional objetiva a descrição e a explanação das línguas focalizando os aspectos pragmático e psicológico, discussões a respeito do entorno comunicativo - em que a motivação e objetivos para a interação verbal são questões centrais e correlações com os processos mentais envolvidos na interpretação e produção das expressões são fundamentais.

Algumas ideias podem ser consideradas nas perspectivas de cada um desses autores como chave na compreensão do funcionalismo: contexto, interação, integração sistêmica, regularidades translinguísticas e processos mentais. Essas concepções estão presentes, em maior ou menor grau, de modo mais ou menos explícito, em todas as pesquisas que se vinculam ao arcabouço funcionalista.

Nesta pesquisa, todos estão bem presentes e representados em ações metodológicas assumidas nos vários momentos da pesquisa. Primeiro: todos os dados são analisados revestidos do contexto de produção, levando em conta o produtor e suas intenções comunicativas em face de seu interlocutor; a análise que desenvolvemos não perde de vista que subsistemas devam ser avaliados e levados em conta para a descrição do dado linguístico; os processos mentais podem ajudar a compreender o deslizamento funcional operado entre um padrão a outro seja por metonímia, seja por metáfora. Também não perdemos de vista que o ocorre em outra variedade da língua, geograficamente distante, pode assegurar o reconhecimento das regularidades.

Essa combinação de vertentes representada por decisões que tomamos durante a escolha das amostras e a seleção de critérios válidos para a descrição e análise dos dados permitem-nos uma conformação ao modelo funcionalista. 


\section{A Gramaticalização numa perspectiva funcionalista}

A gramaticalização pode ser analisada como paradigma (uma visão mais global da mudança tendo em vista o modo como afeta o paradigma-fonte e o paradigma-meta) ou pode ser tomada como um processo (uma perspectiva mais voltada para fases dos deslizamentos operados, de modo a descortinar a gradação implicada).

Neste trabalho, assumimos a perspectiva do processo e visamos à identificação do processo de deslizamento funcional do item afinal. A despeito de descrever um objeto específico do português, temos a consciência de que a gramaticalização é um processo operado nas línguas em geral.

A renovação do sistema linguístico - notada pelo aparecimento de novas funções utilizando formas já existentes e de novas formas para funções já existentes traz à tona a noção de "gramática emergente", ou seja, uma gramática dinâmica, cujas formas linguísticas não são nem fixas, nem determinadas.

Gramaticalização, enquanto processo, tem sido definida por muitos linguistas. Todos, em algum momento de sua conceituação, resgatam a definição primária de Meillet, (1912, apud CAMPBELL \& JANDA 2001:95):

The 'grammaticalization' of certain words creates new forms, introduces categories that did not use receive linguistic expression, [and] transforms the overall system formed.

Para Meillet, é propriedade da gramaticalização a criação de novas formas, geradoras de categorias que causam uma reorganização do sistema. Além disso, Meillet associa gramaticalização a dois processos: analogia (processo pelo qual um novo 
modelo torna-se semelhante a um modelo já estabelecido) e reanálise (atribuição de caráter gramatical a uma palavra independente).

Aproximadamente 50 anos depois de Meillet, Kurylowicz (1965/1975, apud CAMPBELL \& JANDA 2001 p.95) retoma o rótulo gramaticalização para se referir ao crescimento de um morfema que avança de um status lexical para gramatical e de menos gramatical para mais gramatical.

Num grande salto no tempo, mais precisamente em 1982, Christian Lehmann forneceu uma definição mais explícita em um trabalho que foi amplamente divulgado em 1982, revisto ligeiramente em 1985, mas não publicado oficialmente até 1995 (CAMPBELL \& JANDA, 2001, p.95). Segundo esse autor, diacronicamente, gramaticalização é um processo em que lexemas gramaticais se tornam ainda mais gramaticais.

Ainda Lehmann considera a gradualidade como sendo característica da mudança, afirmando que processos semânticos, sintáticos e fonológicos interagem na gramaticalização de um morfema e de construções.

A gramaticalização tem sido estudada maciçamente por diversos linguistas, principalmente após os anos 90. De acordo com Heine, Claudi \& Hünnemeyer (1991, pp. 19-30), o processo de gramaticalização pode ser observável em todas as línguas e pode envolver qualquer tipo de função gramatical.

Segundo esses autores, a gramaticalização ocorreria devido às necessidades de comunicação não-satisfeitas pelas formas existentes no sistema linguístico e à existência de conteúdos cognitivos para os quais não existem designações linguísticas adequadas. 
Outro autor que deu grande colaboração para os estudos de gramaticalização foi Hopper (1991), que traz para discussão a ideia de que a gramática da língua é sempre emergente e nunca presente. Com esse autor, vê-se mais explicitamente aproveitada a ideia de dinamicidade da língua.

Em outro estudo influente, Hopper \& Traugott (1993) definem gramaticalização como processo pelo qual itens e construções lexicais, em certos contextos linguísticos, desempenham determinadas funções gramaticais e, uma vez gramaticalizados, continuam a desenvolver novas funções. Segundo esses autores, gramaticalização pode ser estudada sob aspecto histórico, ou seja, nessa perspectiva envolvem-se as fontes de formas gramaticais e os percursos típicos das mudanças que os afetam. A outra perspectiva é sincrônica, que lida com a gramaticalização fundamentalmente num recorte temporal. Nesse trabalho, os autores inovam ao tratar da gramaticalização dos processos de combinação de orações.

Um dos estudos mais recentes e polêmicos sobre gramaticalização é o de Castilho (2006), em cujos pressupostos teóricos está a ideia de que a língua é um componente pré-verbal, composto por uma espécie de multissistema (esse modelo será melhor explanado no item 2.2). Essa é a razão por que ele admite que gramaticalização é apenas um dos processos constitutivos da língua e pode co-ocorrer com três outros principais processos que têm implicação direta no sistema linguístico; são eles: a lexicalização, a semanticização e a discursivização. Esses conjuntos de subsistemas passariam a ser reconhecidos como processo de criatividade linguística, orientados pelos princípios de ativação (remete a estratégias de projeção pragmática), de reativação (remete a estratégias de retomadas de traços) e o de desativação (remete a 
estratégias de silenciamento). A derivação entre os subsistemas é rejeitada veementemente.

Os estudos de gramaticalização podem ser classificados segundo o tipo de trabalho ou método adotado para análise do fenômeno. Assim é que linguistas podem decidir entre duas perspectivas: diacrônica, se a preocupação do estudo estiver voltada para a explicação de como as formas gramaticais surgem e se desenvolvem na língua, ou sincrônicas, se a preocupação estiver voltada para a identificação de graus de gramaticalidade que uma forma linguística desenvolve a partir dos deslizamentos funcionais a ela atribuído pelos padrões de uso da língua. Há, contudo, a possibilidade de se casar essas duas perspectivas no que se convencionou chamar de pancronia ${ }^{2}$.

Para ser considerada inserida num processo de gramaticalização, uma unidade linguística passa a adquirir propriedades de formas gramaticais ou, se já possui estatuto gramatical, tem sua gramaticalidade ampliada. Sob esta acepção encontra-se a diferença entre unidade lexical e gramatical das formas linguísticas ${ }^{3}$.

\footnotetext{
${ }^{2}$ Temos consciência da polissemia da palavra pancronia: tanto pode designar o estudo contínuo de um corpus organizado sem distinguir as sincronias discretamente, quanto pode designar a soma das sincronias estudadas separadamente. Há, além dessas, a possibilidade de utilizar o recurso de estudar obras sincrônicas e inferir, no conjunto, uma regularidade pancrônica. É o que normalmente se faz com obras lexicográficas representativas de variadas sincronias.

3 O emprego que aqui se faz destes termos serve para diferenciar o conjunto de propriedades que identifica uma e outra categoria. Desta forma, ser lexical identifica categorias prototípicas, cujas propriedades fazem referência a dados do universo social, designando entidades, ações, processos e qualidades, enquanto o predicado ser gramatical identifica categorias prototípicas, por cuidar de organizar no discurso os elementos de conteúdo, por ligarem palavras, orações e partes do texto.
} 
Por fim, há uma gama de estudiosos que desenvolvem suas pesquisas para o entendimento mais aguçado da gramaticalização de itens lexicais para, a partir dela, poder compreender os caminhos que os itens e construções percorrem na língua, para entender sua trajetória como processo, rota e produto, voltando sistematicamente a formar um item-fonte para um novo item-meta, e esse movimento cíclico será contínuo. Faz-se importante, aqui, entendermos a visão dos estudiosos destes ciclos contínuos de mudança gramatical, o princípio e os mecanismos atuantes nessa mudança.

\section{Princípio da Unidirecionalidade}

Martelotta, Votre e Cezário (1996, p. 50) demonstram que o processo metafórico atua unilateralmente num percurso do [+concreto] ao [-concreto], uma vez que palavras do mundo concreto são utilizadas, de forma analógica, para designar conceitos mais abstratos e difíceis de serem conceptualizados.

Para Heine, Claudi e Hünnemeyer (1991), o processo metafórico é unidirecional, o que implica mudanças que são operadas da esquerda para a direita e ocorrem conforme a seguinte escala de abstratização crescente: Pessoa $>$ Objeto > Processo $>$ Espaço $>$ Tempo $>$ Qualidade ${ }^{4}$.

\footnotetext{
${ }^{4}$ No Grupo de Mudança Gramatical do Português, uma crítica a esse continuum vem se fortalecendo. Trata-se da inclusão da categoria PROCESSO em ponto anterior ao da categoria TEMPO. O argumento que sustenta essa crítica diz respeito ao fato de que TEMPO é primitivo em relação à PROCESSO. Isso implicaria que o ponto de inclusão de PROCESSO seria mais à direita no continuum original.
} 
Segundo os autores, cada categoria cognitiva dessa escala constitui um conceito e que sendo a gramaticalização um processo de mudança em que itens lexicais passam a gramaticais e itens gramaticais tornam-se mais gramaticais, constata-se que a abstração metafórica faz parte desse processo.

Citemos neste trabalho dois estudos que ratificam o processo unidirecional percorridos por advérbios. São eles: o estudo do item fora, apresentado por Spaziani (2008) e o estudo do item tipo, tese de Lima-Hernandes (2005).

O estudo desenvolvido por Spaziani (2008) demonstra que os padrões funcionais não são homogêneos em relação à forma e função entre cada padrão. Assim sendo, os padrões representados pelos deslizamentos funcionais da palavra fora denotam uma abstratização que parte de espaço > qualidade. Ainda segundo esta autora, no exemplo: ' aqui fora é melhor prá se trabalhar do que funcionário público (...)', o falante emprega o item fora como excludente de local de trabalho (funcionário público oposto à área da educação) para especificar sua posição no contexto, ele se posiciona como aquele que trabalha com a educação ao utilizar o advérbio 'aqui'. Então a distância entre lá/aqui e dentro/fora demonstra um processo que era físico e se tornou mental, o que indica uma abstratização da categoria de espaço. Dessa forma, haveria um deslizamento metafório de espaço físico para espaço mental.

Muitos são os autores que evidenciaram os deslizamentos funcionais entre as classes de palavras advérbio > conjunção. Essa seta ligando as duas categorias representa o motivo da grande polêmica sobre gramaticalização. Trata-se da direção obrigatória da mudança representada pelo princípio da gramaticalização. 
Para explicar um deslizamento demonstrado em linha, é incluída mais de uma categoria, como ocorre na trajetória parcial da palavra tipo, objeto de estudo de LimaHernandes (2005). Segundo esta autora, os exemplos apresentados como mais antigos, os mais aceitos pela norma culta, associam a palavra tipo à categoria nome e aos traços semânticos [+humano, +animado, +concreto] como nos exemplos de (1a); e com a sua gramaticalização esse item passaria a classificador, associando novos traços [-humano, animado, -concreto], como de (1b).

(1) a. Esse tipo frequenta este bar assiduamente.

b. Gosto desse tipo de perfume.

Hopper \& Traugott (1993), na definição da unidirecionalidade, salientam a especificidade dos contextos discursivos que favorecem a gramaticalização e sustentam que a passagem de [lexical] > [gramatical] não é direta. Assim, a escala [item lexical usado em contextos linguísticos específicos] $>$ [ sintaxe ] $>$ [ morfologia ] demonstra que itens lexicais que passam a gramaticalizados cumprem, primeiramente, funções discursivas, tornando-se sintaticamente fixos e, depois, vindo a formar um morfema. A afirmação básica, dizem os autores,

é que existe uma relação entre dois estágios A e B, tal que A ocorre antes de $\mathrm{B}$, mas não o inverso. Isso é o que se entende por unidirecionalidade. (GONÇALVES, LIMA-HERNANDES, CASSEB-GALVÃO 2007 p. 41 e 42$)$

A seguir, temos o propósito de apresentar dois modelos associados à gramaticalização: O modelo proposto por Hopper (na seção 4.1) e o modelo de Castilho ( na seção 4.2 ). 


\section{Modelos associados à Gramaticalização como métodos de análise}

Tanto para a abordagem da gramaticalização num modelo tradicional quanto da gramaticalização num modelo multissistêmico, o que acontece é que, à medida que as propriedades de uma unidade linguística vão se alternando, ela vai se tornando membro de novas categorias, em razão de uma reanálise categorial, o que permite enquadrar uma mesma forma em categorias diversas. Da adoção de uma ou outra dessas abordagens (gramaticalização como um processo amplo ou língua como multissistema), decorrem exigências metodológicas e implicações quanto à extensão do tratamento linguístico em cada subprocesso e nos demais processos. Esses movimentos, no modelo multissistêmico, poderiam ser apreendidos pelos princípios de: ativação, reativação e desativação.

Como é relevante reconhecer as implicações da escolha de um campo teórico para implementar uma discussão, passaremos à discussão dos modelos de Hopper e também de Castilho.

\subsection{O modelo proposto por Hopper}

Hopper (1991) afirma que é possível identificar um processo de gramaticalização deflagrado já desde seus mais tenros momentos. Para dar conta dessa afirmação, propõe cinco princípios que regem o processo de gramaticalização, como se segue: 
Estratificação - num âmbito funcional amplo, novas formas estão sempre surgindo e coexistindo com as antigas; estas não desaparecem de imediato, o que implica a interação e coexistência das duas formas. Com base neste princípio, funções semelhantes ou idênticas correlacionam-se a itens lexicais particulares ou a registros sociolinguísticos. É um rótulo que se aplica adequadamente à regra variável da sociolinguística laboviana.

Divergência - De acordo com este princípio o item-fonte pode manter traços originais, preservando-se como item independente e, dessa forma, estar sujeito a qualquer mudança no que se refere a sua nova classe gramatical. Este princípio explica a existência de formas em sua origem igual, porém desempenhando funções diferentes.

Especialização - Nessa fase da gramaticalização, há a obrigatoriedade do uso de um item por não haver possibilidade de outra escolha. Essa obrigatoriedade do uso implica no aumento de frequência da forma mais adiantada no processo de gramaticalização.

Persistência - Este princípio favorece o reconhecimento de traços sintáticos e semânticos do item-fonte que permanecem em sua forma gramaticalizada. Isso quer dizer que, mesmo depois de ser gramaticalizado, o item ainda traz sinais da sua origem no modo de organizar-se na estrutura da sentença e de significado do termo.

Decategorização - Nessa fase, os itens/formas perdem ou neutralizam marcas morfológicas e categoriais; portanto, os itens lexicais mais concretos, como é o caso do substantivo, tornam-se itens gramaticais mais abstratos.

O item não precisa revelar todos os princípios para que se ateste a deflagração do processo de gramaticalização. Seriam mesmo princípios que exporiam 
exclusivamente um processo de gramaticalização? Mais adiante, retomaremos essa questão para discutir a pertinência de se lidar com lexicalização.

\subsection{O modelo de Castilho}

Em Castilho (2006), há a afirmação de que a língua é composta por quatro domínios de produção: lexicalização, discursivização, semanticização e gramaticalização. A língua evidenciaria nesse arranjo sua faceta dinâmica e complexa. Vejamos cada um dos processos:

- Lexicalização: “é o resultado do conjunto de itens pertinentes ao léxico ou vocabulário', forma-se a partir do sociocognitivo de caráter pré-verbal para expressão verbal;

- Discursivização: trata do processo de criação do texto e de sua ordenação em gêneros discursivos. $\mathrm{O}$ campo da discursivização pode ser configurado a partir de categorias discursivas, tais quais: organização, reformulação e descontinuação tópica, conexão textual entre outras;

- Semanticização: que é o processo de criação, alteração e categorização dos sentidos. Esse processo compreende a semanticização léxica, a semanticização composicional e a semanticização pragmática.

- Gramaticalização: seria um dos processos possíveis de análise, estudado a partir de subprocessos simultâneos, são eles:

(i) Fonologização: alteração no corpo fônico das palavras;

(ii) Morfologização: alterações que afetam os radicais e os afixos; 
(iii)Sintaticização: alterações que afetam as categorias lexicais, os arranjos sintagmáticos e a atribuição de funções na sentença.

Castilho (2004a, b, 2005, 2006 apud LIMA-HERNANDES, 2009) propõe, em sucessivas reformulações, que o processo de mudança linguística somente pode ser apreendido com base na teoria multissistêmica, cujos princípios atuantes são: ativação (ou princípio da projeção), que diz respeito à escolha de categorias cognitivas e ao agrupamento de traços que comporão a dimensão gramatical, semântica e discursiva de um item e, por extensão, de estruturas; desativação (ou princípio do silêncio), referente ao processo de eliminação de traços previamente escolhidos nos vários sistemas linguísticos; e reativação (ou princípio da correção), que reflete o movimento mental de uma nova ativação de traços lexicais.

Ainda que o autor conceba a língua como um sistema pré-verbal, e por isso priorize a língua-processo, muito do que apresenta ainda se baseia em uma línguaproduto. Também esse modelo remete à minimização do que seja gramaticalização no modelo proposto pelo autor, além do que, propondo que são multissistemas integrados e não derivativos, como poderia gramaticalização e lexicalização explicar um mesmo objeto em seu grau máximo de abstratização? como poderia gramaticalização ter fora de seus domínios básicos a semantização?

Neste capítulo resgatamos aspectos da correlação teórica entre funcionalismo e gramaticalização, explicitando, nas brechas desses pressupostos, a orientação que adotamos para o desenvolvimento deste trabalho.

No próximo capítulo, será relevante a explanação sobre o objeto priorizado para estudo, qual seja, a palavra afinal no português. 


\section{Capítulo II - ASPECTOS METODOLÓGICOS}

Neste capítulo, apresentamos os caminhos (e descaminhos) que culminaram com a elaboração desta dissertação. Trataremos do estudo-piloto previamente feito, momento em que nos perguntávamos se o item afinal teria sido aliciado pelo processo de gramaticalização. Também trataremos das amostras que constituímos ao longo do caminho para elucidar a questão dos padrões funcionais existentes no português.

\section{Uma hipótese de mudança e a elaboração de um estudo-piloto}

Desde o início da redação do projeto que deu origem a esta dissertação, vínhamos intuindo que a palavra afinal passava por processo de gramaticalização, mas precisávamos ter elementos que justificassem um estudo de maior fôlego.

Inicialmente pensamos em constituir uma amostra a partir do corpus diacrônico organizado por Tarallo. Não encontrando dados do item sob análise, selecionamos as transcrições e gravações, o corpus do PEUL-RJ a amostra CENSO-80, contato e recontato, que reúne entrevistas semicontroladas com informantes de diversas localidades cariocas, de pessoas com traços sociolinguísticos bastante heterogêneos.

Em virtude do baixo número de ocorrências encontradas, fizemos incursões pela Amostra ALZIRA. Essa amostra reúne entrevistas com crianças de variadas idades, desde a fase pré-escolar. Já esperávamos encontrar ali um baixo número de ocorrências 
também. Ao mesmo tempo, tínhamos que validar nossas intuições acerca do nicho sociolinguístico mais produtivo com relação a esse tipo de item estudado.

Numa terceira investida, ampliamos o corpus com a consulta aos informantes do NURC-RJ e NURC-SP. Embora o número de entrevistas analisadas do NURC-RJ e NURC-SP fosse menor, a recorrência do item afinal era maior. Lembramos que o NURC reúne informantes com grau superior de escolaridade. Esse achado ratificou nossas intuições sobre a erudição do item estudado. Assim, o item demonstrou-se muito mais frequente no conjunto lexical do falante culto, ou seja, de nível superior completo, do que no do falante que possui no máximo o Ensino Médio.

Tendo em vista que, com o surgimento de novas formas dentro do sistema linguístico que passam a coexistir com as formas antigas, ou ainda que podem se extinguir com o passar do tempo (HOPPER, 1991), o fator externo idade poderia explicar se um uso é mais ou menos inovador. Com base nessa ideia, separamos os informantes por faixa etária, as três adotadas pelos pesquisadores do Projeto NURC, e verificamos que metade das ocorrências é usada por pessoas de 61 a 80 anos e a outra metade divide-se igualmente com as faixas de idade de 21 a 40 e de 41 a 60 anos.

Com base nos resultados observados com as amostras PEUL e NURC, notamos que os usos apontavam para uma mudança em curso já na década de 70. Por essa razão, empreendemos um estudo-piloto que visava especificamente a identificar a atuação de fatores internos. Para dar início à análise, foi necessário estabelecer os critérios a que foram submetidas todas as ocorrências recolhidas dos corpora selecionados.

A quantificação constituía-se, a essa altura, uma tarefa imprescindível para o reconhecimento e validação de algumas hipóteses a priori levantadas. Para esse 
trabalho de quantificação, lançamos mão de alguns programas reunidos no pacote informático VARBRUL - Variable Rules. Os resultados individuais foram correlacionados e, para efeitos de apresentação e melhor visualização, convertidos em distribuição gráfica.

Após a seleção dos informantes, a recolha dos dados, a hipotetização, que gerou uma série de critérios de análise, e tabulação, verificamos que a maioria das ocorrências retratava o item-fonte afinal com uma característica típica de advérbios - sua mobilidade potencial na sentença.

É notório que advérbios são palavras que detêm grande mobilidade sintática, diversamente do que acontece com outras categorias numa oração. Analisar a palavra afinal segundo sua mobilidade sintática pode auxiliar em seu enquadramento categorial. Dessa forma, submetemos o termo ao teste da mudança potencial de sua ordem na sentença no exemplo (1), conforme segue:

(1) E- É? E vem cá, a gente falando de aniversário, seu aniversário é agora em que ano mesmo?

L- Bem, mil novecentos e oitentidois ${ }^{5}$.

E- Bem, e você vai receber alguns amigos em sua casa. Me conta o que é que você está pretendendo fazer?

L- Claro. Eu pretendo ampliar meus... pegar meu bigode de sargento paper, brincar na escola. afinal, eu não posso ficar só aqui. Tenho de me expandir .

\footnotetext{
${ }^{5}$ Este exemplo foi copiado fielmente ao do corpus, contudo acreditamos que haja um erro de digitação no ato da transcrição da palavra oitenta e dois.
} 
Ir pra minha escola e brincar mais e mais e mais. Ah... e tenho mil planos, sabe? (PEUL-RJ 26M Alzira)

.... Afinal, eu não posso ficar só aqui...

...Eu, afinal, não posso ficar só aqui...

...Eu não posso, afinal, ficar só aqui...

A base semântica é sensível a alterações sintáticas que possam ocorrer em muitos casos e com categorias diversas. A despeito do tratamento estilístico ensaiado por muitos linguistas - também claramente enfatizando o efeito de sentido gerado com a mudança de ordem em textos poéticos - aqui, pode-se lançar mão de recurso semelhante para validar a mudança gramatical.

No estudo-piloto, lançamos mão do teste da paráfrase para depreender o efeito de sentido gerado com pequenos deslizamentos funcionais que estejam em operação e, verificamos que o item afinal permitia ser parafraseado com por fim, no final das contas, concluindo, na verdade, pelo fim, a cada fim e depois de muita espera.

Sentidos potenciais em diacronia nem sempre são o fiel retrato do que a sincronia revela como mais frequente em determinada comunidade. Com os dados, observamos que uma frequência maior se combina às seguintes paráfrases: por fim, no final, no final das contas e concluindo. Esses valores, por sua vez, em muitos casos se sobrepõem gerando ambiguidade com depois de muita espera. 
(2) E- Seus filhos foram com a senhora?

F- Não. Eu só tenho um filho, não é? Não, ele já foi- aliás, ele foi uma ocasião, ele era solteiro ainda, foi uma guerra para ele fazer aquela viagem, (riso) porque não se tinha dinheiro, aquela- foi na época que eu trabalhava em <pézinha> no balcão, (elevação) viu? e- (hes) foi uma guerra, mas afinal se consegui. ("Eu") tinha uma tia que morava no- (hes) Portugal. Então ele foi para a casa dela. e (hes) o principal era o dinheiro da passagem, aquela coisa toda. Depois, de lá- ele ficou, lá, uma boa temporada, na casa dela, depois, conseguimos mais um dinheiro, então, ele foi [a]- a Roma, acho que foi à Espanha, esteve em Paris também- Londres é que eu não me lembro se ele foi, (“eu”) acho que não deu <para> ele ir não. Foi só Roma, Paris e Madri. Quer dizer, (ruídos) depois, então, de casado, aí, ele já foi. Já foi com a mulher, (est) tudo- [a mulher está] (PEUL-RJ 62F Censo.)

... foi uma guerra, mas afinal se conseguiu...

... foi uma guerra, mas por fim se conseguiu...

... foi uma guerra, mas no final se conseguiu...

... foi uma guerra, mas no final das contas se conseguiu...

*... foi uma guerra, mas concluindo se conseguiu...

(3) D- E outros delitos menos violentos?

L- Ah! Eu assisti uma coisa horrível aqui defronte de casa. Nós estávamos assistindo televisão, quando eu ouço um barulho como se fosse um estampido de ... Eu pensei que fosse fogos de são João, estava aquela época mais ou menos. Mas meu marido disse: isso é um tiro de revólver. Ele conhece, que é militar. E nós dois corremos pra janela ao mesmo tempo que 
ouvíamos uns passos rápidos correndo e uma pessoa gritando. Aí me debrucei na janela, começou logo juntar gente, juntar gente, juntar gente. Esta rua ficou intransitável. E foi um rapaz que foi baleado, baleado por engano. Ele, a pessoa que baleou, pensou que ele, que se tratasse de um maconheiro que mora um pouco adiante daqui. E aliás eu conheço esse rapaz que é maconheiro. Porque ele chamou pelo nome do outro. E ele instintivamente olhou, ele achou parecido, fisicamente ou a silhueta achou parecido. Estava assim já meio escuro, eu desconfio que até essa noite estava meio chuvosa e ele atirou no rapaz. Bom, atirou no rapaz, o rapaz caiu, foi puxado pra portaria do edifício. Ele gemia, ele gritava: pelo amor de Deus! Tenham piedade! Chamem meu pai! Uma coisa horrível, eu fiquei num, num nervoso que você nem pode imaginar. Aí juntou gente, juntou gente, juntou gente, foram chamar o pai do rapaz. O rapaz ... Um senhor alto de cabecinha branca. Fiquei com uma pena que você não pode imaginar. $\mathrm{O}$ filho baleado (inint.) o rapaz. Depois chamaram, hum, a polícia. Ele pedia pra chamar a, a assistência, mas a assistência não chegava nunca, afinal chegou um carro da polícia, carregaram o rapaz e eu soube depois que o tiro tinha atravessado o intestino, ele resistiu ainda alguns dias e morreu. Isso eu assisti, foi daqui defronte de casa, foi logo depois que eu cheguei aqui em Copacabana. Eu fiquei horrorizada. Ele morreu sem ter culpa nenhuma, né, porque não era com ele. (NURC-RJ - 140F Década de 70)

...mas a assistência não chegava nunca, afinal chegou um carro de polícia...

...mas a assistência não chegava nunca, por fim chegou um carro de polícia...

...mas a assistência não chegava nunca, no final chegou um carro de polícia...

...mas a assistência não chegava nunca, no final das contas chegou um carro de polícia...

*...mas a assistência não chegava nunca, concluindo chegou um carro de polícia... 
...mas a assistência não chegava nunca, depois de muita espera chegou um carro de polícia...

Um dos critérios comumente empregados por sintaticistas é a observação e descrição de contextos em que o item ou estrutura ocorre. Verificamos que o item-fonte, com relação ao contexto anterior, poderia ser antecedido por conjunção e advérbio. Em alguns casos, ainda, o item poderia encabeçar a sentença. Com relação ao contexto posterior, pode ser sucedido por um nome ou pronome, em posição subjetiva, e também por um verbo.

Perguntamo-nos acerca de seu escopo. Teria o item sob análise uma amplitude de escopo como ocorre com alguns advérbios mais gramaticalizados? Poderia ele atuar sobre uma palavra, um sintagma e, até mesmo, uma sentença? Analisamos cada uma das ocorrências e vimos que, se o item afinal fosse avaliado segundo o escopo em combinação com seu contexto sintático, conseguiríamos resolver algumas ambiguidades anteriormente identificadas. Em alguns casos, poderia atuar como:

i) um nó narrativo, que para sua compreensão, contava com a recuperação de toda a história narrada (exemplo 4):

(4) LOC. - ah... as minhas viagens... está muito bem... bom... minhas viagens foram as seguintes... em cinquenta e cinco eu fui para os Estados Unidos por uma bolsa da coca-cola... e fui para a Universidade de Nova Iorque... onde eu estudei um ano de Direito...teRRível... direito americano né... porque você tinha que preparar os casos na véspera pra... pra estudar pra... relatar no dia seguinte né... então a gente tinha que passar três ou quatro horas na 
biblioteca, todo dia até onze horas da noite... depois... onze horas da noite você tinha que fazer o trabalho em casa até duas horas da manhã pra poder trabalhar... teRRÍvel...e ... ( ) ao mesmo tempo muito agradável porque realmente morar em Nova Iorque é um privilégio que é dado a poucos... e... então eu fiquei lá um ano, fiz concurso pra ( )... passei mas não fiquei porque... eu já disse né? depois eu fui mesmo... fui de carro atravessei os Estados Unidos todo de carro e conheci várias cidades... Los Angeles... Washington... e afinal fui parar em Los...ãh... foi... em Washington... Chicago... e fui... acabei parando em Los Angeles né...De Los Angeles eu voltei pra Nova Iorque e de Nova Iorque eu voltei pro Rio... pra o Rio de vez... e em mil novecentos e setenta e cinco pela Cultura Inglesa eu fui... passei um... um mês na Inglaterra... gostei muito... odiei o curso... por sinal uma porcaria... mas foram só dezessete dias... os outros quinze dias eu aproveitei bastante em Londres... que é uma cidade maravilhosa realmente... mas fora isso eu viajei muito... mas foi pra Argentina né... eu fiquei oito meses na Argentina porque eu tinha uma tia... aquela... aquela pseudoportuguesa casou-se com um argentino e foi morar lá... e eu sempre ia... sempre ia lá na casa dela até ela morrer né... ( ) até ela morrer não... até o plano real né... porque realmente eu... a minha vida tornou-se caótica com esse plano real né... bendita inflação... estou doido que ela volte... se tiver algum economista me ouvindo vai me xingar.. vai me chamar de burro... eu não... eu... eu... continuo dizendo que eu era feliz e não sabia... hoje eu trabalho muito mais do que eu trabalhava e não tenho praticamente nada... não tenho regalia nenhuma e... e... o dinheiro não dá... é isso sabe... que mais que eu posso dizer? (NURC RJ 18M Complementar)

ii) uma ligação narrativa, pontual, de dois eventos sequenciado, conforme demonstramos no exemplo (3), aqui retomado:

(3) D- E outros delitos menos violentos? 
L- Ah! Eu assisti uma coisa horrível aqui defronte de casa. Nós estávamos assistindo televisão, quando eu ouço um barulho como se fosse um estampido de ... Eu pensei que fosse fogos de são João, estava aquela época mais ou menos. Mas meu marido disse: isso é um tiro de revólver. Ele conhece, que é militar. E nós dois corremos pra janela ao mesmo tempo que ouvíamos uns passos rápidos correndo e uma pessoa gritando. Aí me debrucei na janela, começou logo juntar gente, juntar gente, juntar gente. Esta rua ficou intransitável. E foi um rapaz que foi baleado, baleado por engano. Ele, a pessoa que baleou, pensou que ele, que se tratasse de um maconheiro que mora um pouco adiante daqui. E aliás eu conheço esse rapaz que é maconheiro. Porque ele chamou pelo nome do outro. E ele instintivamente olhou, ele achou parecido, fisicamente ou a silhueta achou parecido. Estava assim já meio escuro, eu desconfio que até essa noite estava meio chuvosa e ele atirou no rapaz. Bom, atirou no rapaz, o rapaz caiu, foi puxado pra portaria do edifício. Ele gemia, ele gritava: pelo amor de Deus! Tenham piedade! Chamem meu pai! Uma coisa horrível, eu fiquei num, num nervoso que você nem pode imaginar. Aí juntou gente, juntou gente, juntou gente, foram chamar o pai do rapaz. O rapaz ... Um senhor alto de cabecinha branca. Fiquei com uma pena que você não pode imaginar. $\mathrm{O}$ filho baleado (inint.) o rapaz. Depois chamaram, hum, a polícia. Ele pedia pra chamar a, a assistência, mas a assistência não chegava nunca, afinal chegou um carro da polícia, carregaram o rapaz e eu soube depois que o tiro tinha atravessado o intestino, ele resistiu ainda alguns dias e morreu. Isso eu assisti, foi daqui defronte de casa, foi logo depois que eu cheguei aqui em Copacabana. Eu fiquei horrorizada. Ele morreu sem ter culpa nenhuma, né, porque não era com ele. (NURC-RJ - 140F Década de 70)

iii) uma partícula desvinculada sintaticamente, porque atuaria num plano discursivopragmático, conforme exemplo (5): 
(5) INF. - . Não, pra militar eu não tinha vocação. Eu tinha vocação...Não era nem vocação, era um desejo, tanto que aconteceu até um fato curioso, a escola... o concurso já foi feito dentro da escola, dentro da Escola da Aeronáutica, da Escola Preparatória de Cadetes da Aeronáutica, era dentro da Escola da Aeronáutica e era no Campo Dos Afonsos, aqui no Rio de Janeiro. Depois, eles tiraram isso daqui e colocaram lá em Pirassununga , parece. Levaram pra Barbacena, Pirassununga, lá pra aquelas áreas, depois que houve um acidente com dois aviões aqui em cima, que eu vi inclusive um deles caindo. Eu vi os dois caindo, era um avião de instrução da Escola de Cadetes da Aeronáutica, que chocou-se com um avião grande que vinha de São Paulo e tudo. Aí, eles removeram, porque era realmente impraticável ficar fazendo treinamento de piloto no mesmo céu, onde tinha o aeroporto, dois aeroportos e o tráfego já estava mais intenso. Mas, então, eu fui fazer o exame lá, eu e a turma, no dia do exame ...eu já vi uma coisa que me desagradou profundamente. Não quero dizer com isso que, não estou justificando o fato de não ter passado ou tentando me autoconvencer que foi melhor assim, não é isso, entendeu? Mas alguma coisa que realmente me deixou ver que não ia dar certo.. A arrogância dos que já estavam lá, a arrogância dos cadetes. Então, nós chegamos pra fazer a prova e tudo, não é? Dentro de um ambiente militar. Aí, no intervalo de uma prova, a gente foi, no intervalo lá do exame, a gente foi pra uma cantina, cantina dos cadetes pra tomar refrigerante, pra tomar um café, bater um papo. Nisso, chegam alguns cadetes, daqueles bem afinal, eu estava na casa deles, né? Bem arrogantes, né? E começam a, a brincar de uma maneira bem arrogante com alguns candidatos, né? Bom, até que pegou um esquentado e o negócio acabou, o colega que estava lá fazendo a prova acabou tomando uns tapas e teve que ficar com os tapas. E ainda alguns candidatos tentaram se meter e o negócio ia acabar se tornando agressão feia e a parte mais fraca eram os visitantes que eram os candidatos e ficou por ali. Você sabe que aquilo dali marcou, pra mim marcou, marcou e realmente não ia dar certo. Na época, inclusive os trotes eram muito violentos, ainda hoje os trotes ... (NURC RJ 28M Complementar) 
iv) um sinalizador de conclusão, que tanto poderia introduzir quanto interromper uma ideia, ou ainda situar uma ação que possa ocorrer no fim de um determinado tempo.

(6) DOC. - Hoje é difícil não passar um carro ali (sup. ) LOC. - (sup. ) Hoje não dá nem pra atravessar, não é? Então, eu morava ali na pra... ali na rua Visconde Silva mesmo, Botafogo. E tinha aquele negócio de antigamente, tinha turminha de rua (inint. ) Foi lá que eu conheci minha mulher, e ela morava nessa casa que eu moro até hoje. e depois nos casamos, passamos uns tempos desterrados, exilados num apartamento em Copacabana e $\boldsymbol{A F I N A L}$ voltamos pra lá. E estamos lá esse tempo enorme, a nossa vida mudou muito. Eu ... Quando eu casei, eu era muito pobre. Hoje eu tenho uma certa folga financeira, mas por opção consciente, tranqüila , emocional, afetiva e tudo, nós continuamos naquela vila. A casa foi toda reformada mas continuamos ali e somos fiéis ali, não pensamos em mudar. Eu tenho impressão de quando eu sair dali, vou dar, vão dar alguns passos pra mim e me enterram no cemitério que é ali pertinho (risos) é que é bem pertinho, é bem pertinho (sup. ) (NURC RJ 233M Recontato)

No caso de elemento de conclusão, virá posposto a um sequenciador e anteposto a um verbo, encabeçando uma sentença.

Esse primeiro momento da pesquisa foi muito importante para $o$ aprofundamento do estudo. Foi a partir daí que nos motivamos a uma busca mais intensificada sobre o comportamento do item afinal, então fizemos uma incursão em dicionários, gramáticas e 'sites' para conhecer a situação de usos e de orientação de uso divulgada aos consulentes.

Nesta seção, evidenciamos o encaminhamento inicial do trabalho. Ainda que seja derivado de um estudo-piloto feito previamente à pesquisa nesta dissertação 
relatada, de fato esse estudo foi tomado como estratégia de reconhecimento do campo de trabalho. Foi esse ensaio inicial que favoreceu o reconhecimento de critérios que relevantes ao estudo de maior fôlego. Essa é a razão por que consideramos imprescindível incluí-lo nesta dissertação em seção especificamente destinada ao método. 


\section{Capítulo III - AFINAL NO PORTUGUÊS}

Neste capítulo, reunimos informações de caráter normativista, lexicográfico e funcionais. Primeiro, comparamos etimologias e datações oferecidas nos dicionários, depois, passamos pelo cotejo de acepções sincrônicas e, ao final do capítulo, discriminamos os padrões funcionais identificados ao longo do percurso.

\section{Incursão em dicionários}

Consultando Bueno (1968), notamos que a etimologia da palavra afinal estaria associada a finis (indicador de limite final). Afirma o autor que a palavra afinal, que significava "enfim, finalmente", seria um advérbio, cujo surgimento deu-se do seguinte processo de prefixação: $a+$ finalis. Essa informação pôde ser complementada pela datação de 1813, oferecida por Cunha (1986):

Fim SM, 'termo, remate, acabamento' intenção XIII. Do lat. Fini-is. $O$ gênero feminino prevaleceu durante todo o período medieval e chegou até à segunda metade do séc. XVI, embora no masculino o vocábulo já se documente em um ou outro texto do séc. XV \| afinação | afinaçom XVI || afinado XV || afinal 1813 || afinar XVI ||. Do fr. Affiner || alfim XVI || des-afinação XX || des-afinado 1813 || des-afinar XVI I| finado XIV I| final 1813. Do lat. * finitare, deriv. de finitus, parte de finire || findo | fijdo XIII || fineza XVI || finítimo XVII. Do lat. Finitimus \| finito XVI. Do lat. Finitus \| fino adj. 
'delgado, afilado' ‘apurado, refinado' I XIV, fim XIII । Do lat. Finis 'fim', que passou a designar a parte mais perfeita de qualquer coisa, assumindo as acepções de 'perfeito' e, por extensão as de 'refinido, astuto' 'delicado, amável' etc. \| finório XIX \| finura XIX \| infindável 1899 || infindo jmfijmdo XV | Do lat. infinitus || infinidade XVI. Do lat. infinitas -atis || infinitesim AL 1858 || infinitésimo 1858. Do lat. cient. infinitesimus \| infinitivo. ; do lat. infinitus ॥ refinação XX || refinado || refinamento 1858 || refinar XVI || refinaria XVIII II superfino XX.

$\mathrm{Na}$ tentativa de conhecer a origem da palavra afinal, consultamos o dicionário etimológico de Ernout \& Meillet (1959), mas nesta investida não tivemos sucesso e, apesar de não encontrarmos o objeto sob análise, consultamos o termo finis que nos permitiu algumas conexões pertinentes sobre o item-fonte.

O gênero (feminino e masculino) mencionado por Ernout \& Meillet faz com que entendamos que a palavra final $^{6}$ era precedida por artigo feminino e masculino, porém, conforme Nascentes (1966), também final surge com a formação da preposição $a+$ final. Tal preposição pode ser parafraseada por para, o que permite afirmar que para + final dá a ideia de finalização, ou seja, para finalizar, para concluir, por fim e etc. Entendemos que a preposição $a$ é o mesmo que para porque esse autor faz referência à formação da palavra abaixo, que permite uma paráfrase similar com para baixo em alguns contextos.

\footnotetext{
${ }^{6}$ Sabendo que a palavra finis deu origem a finalis e aquela possuía gênero feminino e masculino, entendemos que este gênero se manteve para o novo termo, por isso acreditamos que final tanto podia está precedido por artigo (século XVIII), quanto por preposição ( século XIX ), quando ganha novo significado: para finalizar, para concluir, por fim e etc..
} 
Na verdade, no século XVIII, os dados mostram que tínhamos um adjetivo sendo antecedido por um artigo, porém entre esse artigo e o adjetivo haveria um substantivo (por ex.: o capítulo final) que, depois, torna-se elíptico (por ex.: o final).

No século XIX, temos uma preposição que antecede o termo final e, que a partir daí, passa a dar a ideia de conclusão. Essa forma (preposição + final) sofre contração e o item sob análise passa a ser empregado como um encerramento para aquilo que se tem expressado anteriormente no texto. Com base nos dados, no século XIX, a forma $\boldsymbol{a}$ final, na função de adjetivo, desaparece e o item sob análise passa a ser utilizado sob duas formas a final e afinal sem distinção semântica.

Já Bueno (1968), apresenta a etimologia da palavra classificando-a em advérbio, com o significado de 'enfim, finalmente', que se formou de $a+$ finalis, derivado de finis, 'fim limite'.

Além dos dicionários etimológicos até aqui citados, consultamos Freire (1957) que classifica afinal como advérbio e faz referência à expressão $\boldsymbol{a}$ final, informando que ambas possuem o mesmo sentido:, 'por fim, finalmente, em conclusão, no final, por último'; acrescenta, ainda, as formas nas quais podemos encontrar o item sob análise: 'a final de contas' e 'a final das contas'. Esse lexicógrafo trouxe fragmentos de Camilo Castelo Branco e Valdomiro Silveira para exemplificar o caso:

"cenas grandiosas, que, afinal, desfecham em tragédias que o mundo, fútil e chocarreiro, denomina comédias" (Camilo)

"mas, a final, como quer que Maria perdesse a saúde e amarelasse, o colchoeiro, que não tinha outra filha, deixou-a casar, dotando-a com seis mil cruzados" (Camilo) 
"Uma batalha assim vencida é plena e gloriosa; a outra que vais dar, costuma ser tão golpeada de contrariedades, que a final, o triunfo é sem sabor" (Camilo)

"a final das contas, como nunca não tive ânimo de comprador" (Valdomiro Silveira)

“A final de contas o povo retirou-se..." (Camilo)

As abonações apresentados por Freire representam tanto o PP quanto o PB. Para o primeiro utiliza o modelo da língua literária do século XIX, escrito por Camilo Castelo Branco, um autor fundamental na história da prosa de ficção do português, principalmente como romancista, que representou em Portugal diversas tendências da literatura europeia do século XIX. Camilo Castelo Branco reconstituiu em suas obras o panorama dos costumes e dos caracteres do Portugal de seu tempo (1825 - 1890). Já, para o segundo, o exemplo é de Valdomiro Silveira, que foi contista regional fixando os costumes e tradições paulistas com obras publicadas no período de 1920 a 1941.

Os fragmentos textuais trazidos por esse dicionário permitem verificar que as formas a final e afinal apresentam traços semânticos de fim $^{7}$, mantendo a origem etimológica da palavra que surgiu em 1813, conforme Cunha (1986) e consequentemente conclusivas, já que os exemplos apresentados caracterizam-se por encerrar uma ação mental. Além disso, chama-nos a atenção a falta de diferenciação das formas escritas a final / afinal / a final das contas e afinal de contas. Sobre essa questão, Freire afirma que ambas as formas sob o plano do significado seriam idênticas.

\footnotetext{
${ }^{7}$ Traços semânticos de fim, neste caso, refere-se a idéia de finalização e não finalidade
} 
Acreditamos ser questionáveis tais afirmações desse lexicógrafo, pois apesar de concordarmos com a classificação de advérbio ou até mesmo locução adverbial para as abonações apresentadas, não descartamos a hipótese de outras funções. Seria necessário, contudo, que o contexto dos exemplos fosse ampliado para melhor análise. De qualquer modo, ainda assim, vale a pena ressaltar as abonações do referido dicionário:

"cenas grandiosas, que, afinal, desfecham em tragédias que o mundo, fútil e chocarreiro, denomina comédias" (Camilo)

"A final de contas o povo retirou-se..." (Camilo)

Tanto a expressão a final quanto a final de contas podem atuar como um operador argumentativo de conclusão, admitindo a paráfrase 'portanto', o que dá indícios de uma nova categoria gramatical emergente: a conjunção.

Face ao exposto, perguntamo-nos sobre o estatuto funcional das formas a final das contas / afinal de contas. Seriam, de fato, idênticas a a final / afinal? Entendemos que se tratam de elementos bastante diferentes. Poderíamos hipotetizar que as expressões a final das contas / a final de contas podem ter surgido da área de exatas, no momento em que se finalizava uma conta. Numa alta recorrência do uso, não mais se realizaria todos os itens da expressão. Por outro lado, por um deslizamento metafórico pode ter sido ampliado a outros contextos em que não havia a conta matemática a ser feita, mas que um resultado estivesse implicado. Nesse caso, talvez pudéssemos falar em lexicalização mais propriamente.

Também o dicionário Contemporâneo de Português, de Maria Tereza Biderman (1992), classifica o item sob análise como advérbio com significado de 'finalmente' e 
‘por fim'. Esse mesmo dicionário traz a forma afinal de contas que significa 'concluindo', 'como conclusão' e ‘enfim' com as seguintes abonações:

a) Estavam tão atrasados que pensei que não viessem; afinal chegaram cansados, porque o carro havia quebrado.

b) Afinal de contas, o homem não era tão bravo como parecia.

Os exemplos escolhidos por Biderman trazem o item afinal, que, embora classificados como advérbios, no caso deste último exemplo, conjeturamos também tratar-se de um operador argumentativo explicativo. Notemos que, apesar de manter traços semânticos conclusivos, é possível perceber um certo grau de explicação.

Em Morais (1956), encontramos o seguinte verbete:

Afinal, adv. e conj. (de fim?). Enfim, em conclusão; finalmente: $<<$ Afinal, seu pai sempre te deu licença de saíres $>>$; $<<$ Afinal pus os jornais de lado, e, não sendo tarde, peguei num livro $>>$, Machado de Assis, Páginas Recolhidas,248.

Também foi consultado o dicionário de Língua Portuguesa elaborado por Houaiss \& Villar (2001), que traz as seguintes acepções: por fim, enfim, finalmente, afinal de contas e no final. Ainda, nesse dicionário a etimologia é explicada assim: $\boldsymbol{a}^{-}+$ final; ver fin-.

No Dicionário Aurélio (FERREIRA, 1999), não notamos grande diferença. Além dos sentidos citados no dicionário Houaiss, acrescentou: em conclusão e pensando bem. Talvez Ferreira estivesse se referindo a valores mais populares, já que 
seu dicionário conta com materiais mais diversificados em gêneros e tipos textuais do que o de Houaiss \& Villar, ainda que estes últimos tenham um maior número de documentos em sua base de pesquisa.

Considerando as acepções listadas por cada um dos dicionários consultados, elaboramos um quadro resumo que permite ver tanto as convergências semânticas de época para época, quanto a movimentação semântica dos mais citados nas obras:

\begin{tabular}{|l|c|c|c|c|c|c|c|c|c|c|}
\hline Acepção & $\begin{array}{c}\text { Morais } \\
\text { (1956) }\end{array}$ & $\begin{array}{c}\text { Freire } \\
(1957)\end{array}$ & $\begin{array}{c}\text { Aulete } \\
(1964)\end{array}$ & $\begin{array}{c}\text { Nascentes } \\
\text { (1966) }\end{array}$ & $\begin{array}{c}\text { Bueno } \\
\text { (1968) }\end{array}$ & $\begin{array}{c}\text { Biderman } \\
\text { (1992) }\end{array}$ & $\begin{array}{c}\text { Aurélio } \\
\text { (1999) }\end{array}$ & $\begin{array}{c}\text { Borba } \\
\text { (2000) }\end{array}$ & $\begin{array}{c}\text { Houaiss } \\
\text { (2001) }\end{array}$ & Total \\
\hline Finalmente & $\mathrm{X}$ & $\mathrm{X}$ & $\mathrm{X}$ & & $\mathrm{X}$ & $\mathrm{X}$ & $\mathrm{X}$ & $\mathrm{X}$ & $\mathrm{X}$ & 8 \\
\hline No final & $\mathrm{X}$ & $\mathrm{X}$ & $\mathrm{X}$ & & & $\mathrm{X}$ & $\mathrm{X}$ & $\mathrm{X}$ & $\mathrm{X}$ & 6 \\
\hline Por fim & $\mathrm{X}$ & & $\mathrm{X}$ & & $\mathrm{X}$ & $\mathrm{X}$ & & & $\mathrm{X}$ & 5 \\
\hline Enfim & & & & & & $\mathrm{X}$ & $\mathrm{X}$ & & $\mathrm{X}$ & 3 \\
\hline Afinal de contas & & & & & $\mathrm{X}$ & & & & 1 \\
\hline Concluindo & & & & & & $\mathrm{X}$ & & & & 1 \\
\hline Como conclusão & & $\mathrm{X}$ & $\mathrm{X}$ & & & & $\mathrm{X}$ & & & 3 \\
\hline Em conclusão & & $\mathrm{X}$ & & & & & & & & 1 \\
\hline Por último & & $\mathrm{X}$ & & $\mathrm{X}$ & & & & & & 2 \\
\hline A final & & & & & & $\mathrm{X}$ & & & 1 \\
\hline Pensando bem & & & & & & & & & & \\
\hline
\end{tabular}

Quadro1:Acepções de dicionários

Da observação de preenchimento do quadro acima, nota-se que os lexicógrafos, quase unanimemente, destacam em primeira posição a acepção finalmente. Em segundo lugar, temos a acepção por fim; em terceiro, segue na lista a acepção enfim; em quarta 
posição, seguem empatadas as acepções no final, afinal de contas e em conclusão; em quinto lugar, temos a final; e, em último lugar, representando a sexta colocação, apresentam-se também empatadas as acepções concluindo, como conclusão, por último e pensando bem.

Já com algumas elucidações dos dicionários e algumas hipóteses levantadas, acreditamos que poderíamos obter mais esclarecimentos do item estudado, fazendo uma incursão nas gramáticas normativas de Língua Portuguesa. Como informação complementar, consultamos informações da internet, em que esperamos encontrar "conselhos" de como se deve empregar o item sob análise.

\section{Incursão em gramáticas e internet}

A gramática tradicional faz uma breve menção sobre o uso de afinal. Essa menção é feita por Cunha \& Cintra (1985), que o denominam de partícula de realce e palavra denotadora de situação. No que se refere a constituintes integrados às sentenças, podemos encontrá-lo nos dicionários, na classe dos advérbios.

Outros materiais também foram consultados, é o caso da Moderna Gramática Portuguesa, de Bechara (1999) e Gramática de usos do português de Neves (2000), porém ambos não tratam diretamente do item sob análise, apenas fazem alusões a outros advérbios. Esta última autora trata a respeito do advérbio finalmente, que segundo ela, é 
o mesmo que no final, para encerrar e são palavras de situação relativa, ou seja, a situação pode ser referida a um momento da enunciação ou do enunciado (fóricos).

Exatamente por não localizarmos muitas informações nas gramáticas sobre a palavra analisada é que buscamos na internet informações sobre o que se orientava aos consulentes de gramáticas e manuais gramaticais.

Vale lembrar que, desde o início deste trabalho, estamos apontando para o estudo da palavra afinal, contudo alguns dicionários citados no tópico 1 deste mesmo capítulo, mencionaram que a expressão a final e a palavra afinal têm o mesmo significado.

Isso explica o que encontramos num site da internet. Deparamo-nos com uma matéria sobre a expressão a final, e acabamos sendo surpreendidos com a relação observada entre a expressão citada e a palavra afinal. Leiamos a matéria destinada àqueles que preferem andar afinados com a norma culta:

André Alexandre Hapcke e Guilherme Casali, ambos de Florianópolis/SC, solicitam esclarecimentos a respeito de expressão muito utilizada em sentenças e acórdãos: a final ou AO FINAL. Exemplifica André: "Requer, ao final / a final, a condenação do réu". Ambas corretas. Note-se, porém, que a locução escrita com a preposição "a” é antiga. Essa grafia já não aparece em dicionários atuais, tendo sido substituída por afinal ou AO FINAL, locução adverbial que significa "na última parte, no fim, na conclusão /desenlace/remate, ao termo /término".

$\mathrm{O}$ advérbio afinal (ou afinal de contas), além de significado semelhante - por fim, finalmente, enfim, em conclusão, em 
resumo - apresenta algumas nuances de interpretação, podendo expressar indignação, contrariedade, surpresa/espanto, melancolia, resignação, ou algo como "pensando bem". Exemplos:

Afinal, o que fazer da vida depois da tragédia?

"Disse-lhe que, a final de contas, a vida de padre não era má."

(Machado de Assis)

[In: Não Tropece na Língua no 093 - 2a Edição de 09/02/2008, disponível

no site:http://redacaoescola.blogspot.com/2008/02/afinalao-final-anteoante-ao-subscrever.html]

Embora o site contivesse a informação de que o emprego das duas formas estaria correto, comparando algumas paráfrases com o exemplo dado por André (pessoa que questiona sobre o uso do item sob análise) é possível verificar que a expressão ao final (um delimitador ora de tempo ora de um fato / ação) necessita de um SN especificando o que está sendo delimitado.

Apesar de, no exemplo dado pelo consulente, não haver essa especificação, podemos inferir o complemento do julgamento. Isso indica que há diferença semântica entre os itens. Comparemos as paráfrases:

Exemplo de André: (A) Requer, ao final, a condenação do réu.

A1 ) Requer, ao final do julgamento, a condenação do réu. 
A2 ) Requer, no fim do julgamento, a condenação do réu.

Em A1, a expressão ao final indica que, no momento (presente) da enunciação, há um pedido (ação mental) a ser realizado no momento futuro (ação física). Esse futuro é determinado pela expressão 'ao final do julgamento', ou seja, quando se solicitará a condenação do réu. Essa expressão ao final, também pode indicar que não é necessário finalizar o julgamento para se fazer a solicitação da condenação, mas que este pedido possivelmente feito antes da seção do julgamento deverá ser solicitado durante o período (processo) de finalização da seção. Percebamos que não há uma precisão do tempo. Em A2, diferentemente, é possível perceber essa maior precisão de tempo para que seja feita a solicitação de condenação, pois é necessário chegar ao momento final e, então, se realizar ação física. Portanto a noção de abstratização é maior em A1 do que em A2, ainda que em ambos haja uma finalização física.

\section{B) Requer, afinal, a condenação do réu.}

B1) Requer, portanto, a condenação do réu.

B2) Requer, concluindo, a condenação do réu.

B3) Requer, na verdade, a condenação do réu.

Em B1, B2, e B3, as paráfrases demonstram não haver necessidade do complemento nominal, diferente do que aconteceu em A1 e A2 que permitiram até mesmo a inferência. Acrescentamos, ainda, que comparando o grau de abstratização 
entre A1, A2 e B, B1, B2, B3 estes quatro últimos foram os mais abstratos, pois atuam foricamente encerrando a ação mental.

Mais uma explicação voltada ao contexto linguístico específico da área jurídica foi identificada:

Esclarecimentos a respeito de expressão muito utilizada em sentenças e acórdãos: a final ou AO FINAL.

"Requer, ao final, a condenação do réu... / Requer, a final, a condenação do réu".

Comecemos por dizer que "a final", como locução, não tem embasamento gramatical. É uma deturpação gráfica de 'afinal' com 'ao final' (= no final). Existem duas grafias corretas, cada qual com seu uso próprio:

1. afinal: advérbio, significa "por fim, finalmente, enfim, afinal de contas": Afinal, vamos ou não vamos?

O autor do crime foi condenado, afinal - já não era sem tempo.

Mas não é esse o termo a ser usado nos documentos jurídicos, pois ali juiz ou desembargador se refere ao fato de, no fim da petição, ter sido requerida a condenação do réu (ou questão semelhante), caso em que deve se valer de:

2. ao final: locução adverbial formada pela prep. $a+o+s u b s t$. final (= fim), tem por significado "na última parte, no fim, na conclusão, desenlace, remate, ao termo/término".

Afinal, Redação Jurídica

M. T. Piacentini 
A matéria escrita por Piacentini (s/d) parece bastante convincente aos consulentes ao afirmar que $\boldsymbol{a}$ final, como locução, não tem embasamento gramatical e se trata de uma deturpação gramatical com ao final, contudo não só a matéria de Piacentini, mas também a da revista Não Tropece na Língua, anteriormente comentada, estão incompletas, não explicando claramente o uso linguístico. A explicação do professor com relação à expressão "ao final" precisa de mais elementos do que ele seria capaz de dar se se baseia somente na repetição cega de uma expressão em petições jurídicas.

Por outro lado, não poderíamos contar com um resgate histórico da sintaxe original, uma vez que o uso recorrente corroi elementos que podem ser inferidos. Lidamos com informações pressupostas sem necessariamente expressá-las no corpo das sentenças. O efeito desse apagamento sistemático pode ser lido em termos de seu esquecimento histórico: dada a alta recorrência com elipse do sintagma nominal (LIMA-HERNANDES, 2009; DEFENDI, 2008) conforme demonstramos com os desdobramentos efetuados nos exemplos apresentados em A e B.

\section{Comportamento funcional: identificando os padrões funcionais}

A transferência entre domínios funcionais provoca o deslizamento de um sentido mais concreto para um mais abstrato numa linha unidirecional. 
Assim sendo, a escala de abstratização é crescente e ocorre da esquerda para a direita conforme Heine, Claudi e Hünnemeyer (1991), que explicam um deslizamento representado em linha, na qual é incluída mais de uma categoria, como ocorre na trajetória parcial das palavras a final / afinal que passam pelo processo de metaforização.

Para que possamos checar a metaforização do item a final / afinal, tomemos por base o percurso: [+concreto] $>$ [+abstrato]. Para tanto, consideremos as acepções elencadas por Ferreira em seu Dicionário Aurélio.

A primeira acepção associa o item sob análise aos sentidos de por fim, finalmente e afinal de contas, permitindo que sua caracterização do mundo físico [+concreto] marque o fim de uma sequência de ações, de um fato, conforme podemos verificar nos exemplos a seguir.

(7) nem presumir consolá-la; era a primeira. Até então, ambos nós só conhecíamos os trocos miúdos do amor; e, por desgraça dele a primeira moeda grande que achara, não era ouro nem prata, senão ferro, duro ferro, como a do velho Licurgo, forjada como mesmo amargo vinagre. Não dormimos. Norberto chorava, arrepelava-se, pedia a morte, construía planos absurdos ou terríveis. Eu, arranjando as malas, ia-lhe dizendo alguma cousa que o consolasse; era pior, era como se falasse de dança a uma perna dolorida. Consegui que fumasse um cigarro, depois outro, e afinal fumou-os às dúzias, sem acabar nenhum. Às três horas tratava do modo de fugir ao Rio de Janeiro, - não logo, mas daí a dias, no primeiro vapor. Tirei-lhe essa idéia da cabeça unicamente no interesse dele próprio. - Ainda se fosse útil, vá, disse-lhe eu; mas ir sem certeza de nada, ir dar com o nariz na porta, porque a mulher, se não gosta de ti, e te vê lá, é (CP Séc XIX:Machado:Eterno) 
(8) Pois que agora lhe devolvera o quadro, com uma carta muito seca, dizendo que afinal Corot não era dos pintores da sua predileção... (Botelho, Abel: Amor Crioulo, p. 382).

Essa marcação de fim é que caracteriza o fenômeno de advérbio e, consequentemente, seus traços semânticos estão associados ao traço [ +concreto ].

Já em a final percebemos o processo metafórico mais presente, referindo-se a noções mais abstratas, como em (09), (10) e (11):

(9) estar a supervisar uma coisa em que eu próprio estava a trabalhar, e optei em ficar apenas fora. Para além de que faz sentido o que disse há bocado: OK, aqui sou só compositor! npt-pub-7380\#\# De entre o grupo de vencidos, logo ressalta o nome de Earvin Magic Johnson, não só por ter sido a última grande vedeta a cair perante Jordan, como, e sobretudo, por constituir com ele o par de os maiores entre os grandes. Hoje por hoje, são as duas grandes estrelas de o basquete mundial. Aliás, a final entre Bulls e Lakers era o momento ansiado por todos os adeptos de a modalidade exceptuando, obviamente, os adeptos de os outros contendores de a NBA, não tanto por opor os homens de Chicago a os de Los Angeles, mas por colocar frente a frente Jordan e Johnson. Jordan ultrapassou Magic Durante as últimas temporadas, foi frequente a comparação entre Magic Johnson e Michael Jordan. Tudo servia para esse objectivo. As estatísticas de os jogos, as actuações em os diversos All Star Game, as atribuições (CP Séc XIX Pt:Público) 
(10) Assista ao vivo a final entre Brasil e Estados Unidos dia 21 (quinta-feira) as 10h00, que ocorrerá no estádio dos Trabalhadores em Pequim. ${ }^{8}$ (site esportivo Noticiaki)

(11) Para chegar a final o Brasil derrotou a Alemanha por 4 a 1, e os Estados Unidos derrotaram o Japão por 4 a $2^{9}$. (site esportivo Noticiaki)

Ainda em (09), (10) e (11), o item a final, embora, com base na gramática normativa, possa ser categorizado como artigo e substantivo respectivamente, permitenos inferir a ideia de que o substantivo partida (a partida final) fora elidido da sequência. Essa suposta elisão teria permitido uma recategorização, portanto.

No exemplo (12), é possível postular um grau de abstratização diverso do anterior:

(12) Paulo Coelho: afinal, ele escreve bem? ${ }^{10}$ ( Revista Língua Portuguesa )

8 O exemplo (10) é um dado retirado do site esportivo Noticiaki: http://www.noticiaki.com/2008/08/assista-ao-vivo-final-entre-brasil-e.html. Consideramos importante mantê-lo, pois é um exemplo do PB e em momento oportuno pode ser comparado com o exemplo do (09) que é do PE.

9 Neste contexto, $\boldsymbol{a}$ final atua na posição de substantivo, nela está subententido a expressão partida, sendo que a ausência não causa prejuízos de entendimento do texto.

${ }^{10}$ Exemplo retirado da revista Língua Portuguesa 
O item afinal seguido por uma pausa (marcada pela vírgula), que por sua vez é sequenciada por uma interrogativa parece esvaziado de sentido. Na verdade, desempenha um papel mais abstrato de operador argumentativo.

Ao levar em conta o continuum proposto por Heine, Claudi \& Hünnemeyer (1991), qual seja: pessoa $>$ objeto $>$ atividade $>$ espaço $>$ tempo $>$ qualidade, bem como o que aqui foi exposto a respeito do item afinal, verificamos que o princípio da unidirecionalidade contribui para a compreensão dos diferentes usos do item sob análise, ainda que não passe por todas essas categorias cognitivas em seus deslizamentos funcionais.

Também como demonstrou Spaziani (2008), ao analisar o item fora, o grau de abstratização pode ser maior ou menor dentro de uma mesma categoria cognitiva. Assim, o fato de se encaixar uma função numa determinada categoria cognitiva não implica que todos os dados desse mesmo conjunto se situem no mesmo grau de gramaticalização. Imaginamos que o item afinal, dada sua opacidade semântica em alguns dados, possa depender de categorias intermediárias para sua explicação.

Organizando os dados em conjuntos de semelhantes funções, chegamos a quatro padrões funcionais, explicitados a seguir:

- a final 1: adjetivo recategorizado em substantivo devido à elipse do substantivo "partida" (por metonímia), o que desencadeou a aproximação do adjetivo a um artigo. Essa aproximação (por reanálise) permitiu a recategorização desse adjetivo em substantivo. Com essa recategorização passará a assumir as características dessa nova classe: admitindo a anteposição de um determinante ou mesmo a modificação por um novo adjetivo que se apresente à sua esquerda ou direita. Trata-se de um processo de lexicalização. 
(13) a final da Taça de Portugal é, então, uma boa oportunidade para se redimir das oportunidades não concretizadas no jogo do campeonato?(CP Séc. XX Or:Pt:Intrv:Jrnl)

(14) A mulher do Silveira não enjeitava partido, muito ancha e pimpona. Quando dançava, via-se-lhe a saia tremer sobre os quadris, ao ritmo das violas, que acompanhava às vezes na boca: pcht, pcht, pcht, pcht.. Os cantadores largavam a goela no mundo, impregnando no verso a volúpia do baião: Todo branco quer ser rico, Todo mulato é pimpão, Todo cabra é feiticeiro, Todo caboclo é ladrão. Viva Seá Dona Guidinha, Senhora deste sertão. Prolongavam muito determinadas sílabas num misto de canto e de aboiado, principalmente $\boldsymbol{a}$ final do último verso. Às vezes a modulação parecia ir com aquele pinotear cadenciado do rojão: $\mathrm{O}$ fogo nasce da lenha, A lenha nasce do chão; $\mathrm{O}$ amor nasce dos olhos, $\mathrm{O}$ afeto do coração; A ira vem de repente, Mais a raiva vem do Cão; A amizade vem da estima, Do fervor a gratidão; O home dá valimento, Mas só Deus dá salvação.. Menina, dá-me teus braços, Que eu te dou meu coração! Todo letrado é ladino, Todo frade(CP Séc. XIX:Oliveira:Guidinha)

- afinal 2 / a final 2: advérbio parafraseável por 'finalmente', 'por fim', 'enfim', 'no final' entre outras expressões que determinam finalização. Recategorizado como advérbio, assume posição sintática mais maleável e assumindo um caráter mais parentético. Associa-se à marcação da fase final de um evento anteriormente citado indicando o alívio do falante perante essa mudança de estado. Associa-se mais francamente a sequências tipológicas narrativas. Trata-se de um caso de gramaticalização. 
(15) parecia-me duro demais para os seus olhos. Não queria que visse os corpos, dos seus pais e dos seus irmãos, nos meus braços de lavrador carregados como fardos. Tempo não havia para arrumar os corpos na grande cova. Quase correndo, voltando a sujar-me do sangue dos infelizes, carreguei um a um até que a cova se encheu. Sob o fogo dos fachos, era uma trincheira de guerra. E, um pouco exausto, movendo a pá, cobri com a terra de Januário a sepultura da sua gente. Meu corpo cansado, afinal, pôde sentar-se. O suor lavava o sangue dos mortos nos meus peitos. Gritei, chamando a mulher e o menino. Tínhamos que nos banhar na cisterna e par_tir o mais cedo possível. Após o banho - eu vestindo uma roupa de Januário e o afilhado, de roupa limpa, já com a trouxa de seus pertences -, e depois que fechamos a casa, pensei nas providências para conduzir as armas e as munições. Antes, com minhas próprias mãos, amarrando as achas de lenha( CP Séc. XX:Fic:Br:Aguiar:Corpo)

- afinal 3: operador argumentativo que sinaliza que a informação sucedente é irrefutável por ser óbvia. Pode ser parafraseado por 'uma vez que', 'já que', 'porque' e 'pois', o que denota seu caráter explicativo. Do ponto de vista do interlocutor, seu emprego tem a função de conduzir o raciocínio para uma conclusão óbvia que valida a tese do falante. Prosodicamente, exige uma marcação típica de finalização de fala. Trata-se de um caso de gramaticalização.

(16) Pepetela - Mas, aqui, vejo uma coisa curiosa: a ruptura surge na minha vida pessoal muito antes que em minha obra. Como se na minha escritura essa ruptura custasse mais a vir à tona. Talvez porque o travo amargo que vivi em meu dia-adia, em minha ruptura com o aparelho do poder, tenha ressalvado sempre uma certa dose de otimismo, de esperança. Seguimos, até hoje, um caminho minado e as esperanças e utopias foram ruindo, uma a uma - menos a essência do ser humano. Partimos, hoje, de um outro nível: afinal, o longo e amargo percurso de 
nossa história mais recente indica que pelo menos tivemos a oportunidade de criar uma nação. Já é alguma coisa.

Estado - Você diz que em Angola as utopias foram ruindo?

Pepetela - Acho que não apenas lá. Ou, pelo menos, as utopias com as quais convivemos durante quase um século.

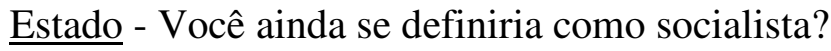

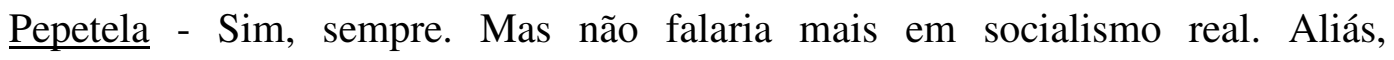
muitíssimo antes da queda do Muro (CP Séc. XX Or:Br:Intrv:ISP)

(17) Fava - dezembro, vamos contabilizar 40 reuniões, sendo que a última será realizada sob a responsabilidade da próxima gestão. Se eu quisesse ser autoritário eu cumpriria exclusivamente o que a letra estatutária manda.

Estado - Em diversas ocasiões o senhor falou sobre a importância de aproximar a universidade da sociedade. No entanto, entrará para a história da USP como o reitor que fechou o câmpus à comunidade. Como encara essa contradição?

Fava - Eu não fechei o câmpus. O uso dele está restrito aos domingos e feriados. Quem quiser vir de segunda a sábado será bem-vindo; afinal, isso aqui não é um parque de diversões e sim uma universidade. Aqui não há banheiros públicos e estrutura que permitam a realização de grandes espetáculos. No exercício anterior o câmpus havia sido absolutamente degradado. Tínhamos áreas alugadas por intermediários para jogar futebol. Uma vez fizeram um espetáculo pirotécnico a 400 metros do Hospital Universitário.

Estado - Como o senhor chegou à decisão de restringir o uso do câmpus?

Fava - Essa decisão não foi tomada arbitrariamente. Nós esperamos o Parque Villa-Lobos ser aberto para tomar a (CP Séc. XX Or:Br:Intrv:ISP) 
- afinal 4: marcador discursivo de indagação. Com esse emprego, o falante sinaliza que não consegue reunir, a partir das informações citadas, elementos que permitam inferir uma resposta. Em alguns contextos, pode ter sua função próxima a de um introdutor de pergunta retórica. Trata-se de um caso de gramaticalização.

(18) Bento nos braços de seu Jesus - mamãe sabia das coisas, se não agisse o agido, quem previa as consequências? Achegou-se mais à morta - três vezes lhe dera a vida: uma no nasci-mento, a outra no casamento de desastrada memória, a terceira quando lhe impôs Jesus; desenvolvesse em seu ventre uma criança-menina, chamá-la-ia Sofia, parecesse com a avó, chegaria a princesa. ao escutarem Sofia, todos se aquietaram, inclusive Paulo Bento já alcançando o intento de esganar o canalha - coitado, não tinha culpa, também passara vergonha, quem, afinal, é culpado de criar um filho doido? O homem soltou-se, aflito, arrumou o colarinho, consertou a elegância. Voz humana, bem usada, guardava a força de Deus, refletiu Tecla Bento soluçando, de novo abraçada à tia lembrava daquela hora, recobrava os sentidos e sentiu-se confiante, como se a embalasse o anjinho da coroa e não apenas a mãe. Pensou e olhou o anjo. Encantou-se com o milagre da presteza do bom Deus - conhecia o espertinho, nascera nas asas dele e(CP Séc. XX Fic:Br:Abreu:Santa)

(19) forte. Segundo ponto é o governo. Eu tenho um governo com obras e realizações visíveis, que as pessoas enxergam e sentem. E isso tem um componente de opinião pública. A manifestação popular tem sido toda a nosso favor.

Estado - O senhor acha que no dia da votação haverá uma pressão popular inversa à do dia da votação do impeachment de Collor?

Paulo Afonso - Vamos ter a praça superlotada de pessoas contra o impeachment. Falam em mais de 20 mil pessoas. E é uma coisa que deve pesar na análise dos deputados.

Estado - afinal, qual é a sua responsabilidade nesse episódio? 
Paulo Afonso - Minha responsabilidade está na operação em que participaram outros órgaos, como o Senado, o Banco Central e a própria Assembléia. Nunca disse que não participamos, mas fizemos tudo dentro da regra estabelecida. Minha responsabilidade termina no instante da primeira colocação dos títulos, a colocação primária, sobre a qual nós temos controle. A partir dali, o que ocorre no mercado financeiro não tem controle da parte do Estado.(CP Séc XX Or:Br:Intrv:ISP)

\begin{tabular}{|c|}
\hline Padrões funcionais de AFINAL \\
\hline a final 1 substantivo derivado de adjetivo \\
\hline $\begin{array}{l}\text { afinal } 2 \text { / a final } 2 \text { - advérbio que sinaliza o } \\
\text { alívio resultante do término de um evento. }\end{array}$ \\
\hline $\begin{array}{l}\text { afinal } 3 \text { - operador argumentativo explicativo, } \\
\text { sinalizador de que a informação antecedente é } \\
\text { irrefutável e óbvia. }\end{array}$ \\
\hline afinal 4 - \\
\hline
\end{tabular}

Quadro 2: Resumo dos Padrões funcionais

Como o primeiro padrão atende ao processo de lexicalização, ficará excluído do continuum unidirecional que projetamos a seguir:

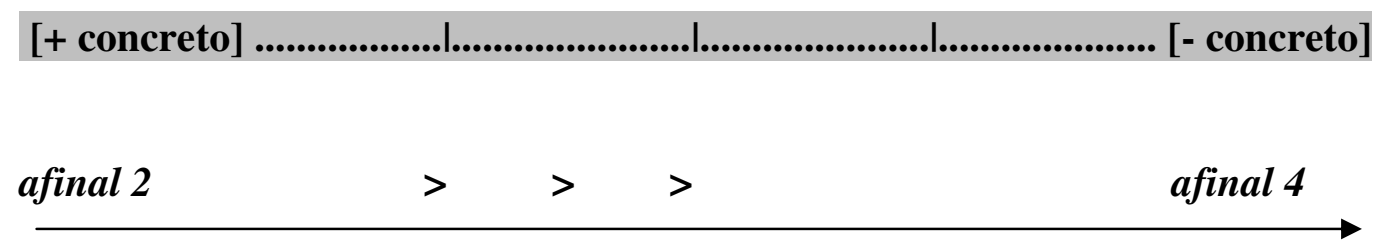

Continuum 1: concretude do item

Essa linha unidirecional mostra que as mudanças são operadas da esquerda para a direita e, nesse caso, de categorias mais próximas do indivíduo, e mais concretas, para categorias cognitivas mais distantes do indivíduo, as menos concretas. 
Além disso, a gramaticalização, sendo um processo dinâmico, reflete não somente o movimento contínuo da estrutura, mas ainda uma atividade cognitiva com reflexos na própria estrutura, conforme afirmam Heine, Claudi e Hünnemeyer (1991 apud LIMA-HERNANDES, 2005, p.28), o que podemos perfeitamente confirmar com dados que colecionamos da palavra afinal, já elencados como divergentes quanto à função.

Ainda alertam os autores que a gramaticalização pode ser motivada por analogia (em que o falante/locutor num processo cognitivo percebe a similaridade e passa a utilizar o item sob análise de modo inovador) ou pela reanálise (em que o falante/interlocutor faz uso do item em uma nova estrutura sintagmática); tal processo de mudança pode ser representada num continuum que tanto envolve a variação conceptual quanto a contextual (idem, ibidem).

Essa direção de mudança pode ser linear ou alinear, embora nem esta nem aquela rompam com a unidirecionalidade. No caso do "a final 1", temos um caso de lexicalização, mas nos demais lidamos com gramaticalização. Há, aqui, uma unilinearidade representada em direções opostas:

$$
\text { lexicalização }<\quad \text {------- > gramaticalização. }
$$

Continuum 2: unilinearidade /unidireção

Proposta a organização unidirecional e unilinear dos padrões afinal 2, afinal 3 e afinal 4 (gramaticalização), ao mesmo tempo em que 'a final 1' reverte o continuum numa direção de maior concretude (lexicalização). 
Se estivermos corretos em nossa análise, então teremos que rever os princípios de Hopper como fundamentais de qualquer mudança linguística operada. Tanto para lexicalização quanto para gramaticalização, há persistência de traços originais (princípio da persistência), há novas regras variáveis instaurada ou ampliadas (princípio da estratificação), há a incorporação de novos comportamentos derivados da nova categoria assumida (decategorização). 


\section{Capítulo IV - Estudo comparativo dos padrões funcionais de AFINAL nas variedades PB e PP}

Um dos questionamentos levantados nesta pesquisa é se o item afinal, objeto de interesse nesta pesquisa, apresenta os mesmos padrões funcionais nas duas variedades da língua portuguesa: o PB e o PP.

Se, de um lado, os gramáticos históricos e linguistas, de modo geral, afirmam que o PB é mais conservador, por outro lado, reconhecemos que nem sempre os linguistas portugueses defendem que os falantes do PB alteraram, no uso, de modo substancial a língua lusitana.

Consideramos que é possível reconhecer a similaridade e/ou a diferença entre as duas variedades, pelo menos no que se refere ao grau de gramaticalização do item afinal. Perguntamo-nos, então, se o PP teria desenvolvido mais padrões funcionais do que o PB, dado o caráter conservador deste último.

Para essa empreitada, lançamos mão de dados do PP e PB contemporâneo, de onde retiraremos e classificaremos os padrões funcionais do item afinal. Depois, procederemos à comparação das diferenças/similaridades entre os padrões funcionais identificados.

\section{Padrões funcionais da palavra afinal no PP}


Partindo de padrões já identificados em nosso corpus apresentaremos os padrões funcionais que ocorrem no PP no século XX.

a) a final 1: adjetivo recategorizado em substantivo devido à elipse do substantivo "partida" (por metonímia), o que desencadeou a aproximação do adjetivo a um artigo. Trata-se de lexicalização.

(20) ... de prolongamento. Final Mas a maior surpresa de todas estava reservada para $\underline{\text { a final }}$. Com um país inteiro nas ruas a torcer pela selecção, e uma equipa...(CP Séc XXAc:Pt:Enc)

(21) ...em juniores, na praia do Pedrogão, existindo ainda a hipótese de $\underline{\boldsymbol{a} \text { final }}$ vir a ser disputada em Leiria». \# np_ler_17\#\# \# Helder Roque considera-se o candidato.... (CP Séc XX N:Pt:Leira)

(22) ...relva, o vencedor foi o norte-americano Richey Reneberg, que bateu em $\underline{\boldsymbol{a}}$ final o francês Stéphane Simian por 6-4, 6-0. npt-pub-302\#\# Espectáculo de um jovem grupo ... (CP Séc XX N:Pt:Público)

(23) ...com 56,02m, mas não chegou. Foram precisos $61,22 \mathrm{~m}$ para ir a $\underline{\boldsymbol{a} \text { final. }}$ Quem brilhou de manhã foi Lucrécia Jardim Benfica, em a eliminatória de 200m... (CP Séc XX N:Pt:Público)

(24) ...do Mundo de Atletismo, em Atenas, conseguiu o apuramento directo para

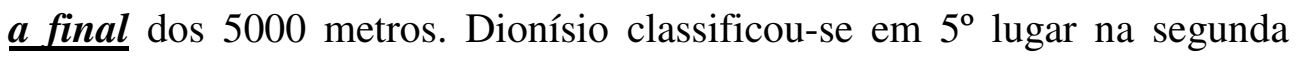
meia-final. A final... (CP Séc. XX N:Pt:Expr)

(25) .......Núcleo Sportinguista de Leiria na categoria de cadetes, são os apurados para $\underline{\text { a final }} \underline{\text { da Taca }}$ de Portugal em ciclismo, que se vai disputar no Porto. \#...(CP Séc. XX N:Pt:Leira) 
Estes dados (do número 20 ao 25) mostram que o item a final, em seu gênero feminino, está antecedido pelo artigo, e nessa estrutura é amplamente difundido no léxico esportivo e em especial no futebolístico. Em muitas das ocorrências do século XX, o próprio item já traz em sua carga semântica a palavra partida, competição ou ainda em um contexto menos comum a palavra prova.

b) afinal 2 (advérbio): este grupo engloba os casos em que afinal determina uma finalização. Aparece no final de um texto como sinalizador de raciocínio conclusivo, podendo ser em sua maior parte anafórico, já que retoma contexto anterior e apresenta uma conclusão finalizadora das ideias já expressas no texto. em consequência, alguns milhares de portugueses em situação defraudante e a todos os títulos injusta para quem, ao longo de 3 ou 4 décadas, se dedicou e consagrou a uma carreira pública que sempre foi e continua a ser o esteio e o suporte da estabilidade e da governabilidade de um país com perto de 900 anos de história. Pelos vistos, ao ser reconhecida pelos poderes públicos a injustiça praticada, algumas medidas correctivas foram tomadas pelo Governo. Porém, quando seria de esperar que as mesmas se entendessem a todos os portugueses atingidos e afectados, verificou-se que afinal só alguns grupos de profissionais foram objecto de preocupação e de selecção, deixando transparecer, mais uma mais iguais do que outros. Com efeito, logo de seguida, foi promulgada a Lei n. $2 / 90$, de 20 de Janeiro, aplicável somente aos magistrados, dispondo no seu art. ${ }^{\circ} 3 .^{\circ}$, n. $^{\circ} 2$ e 3, o seguinte: " As pensões dos magistrados públicos são automaticamente actualizadas e na mesma proporção (CP Séc. XX: 19N:Pt:Jornal)

c) afinal 3 (operador argumentativo): Pode ser parafraseado por 'pois', o que denota seu caráter explicativo, além disso valida a tese do falante conduzindo-o a um raciocínio conclusivo. 
foi a EDP que vedou e policiou toda a área onde foram descobertos os achados arqueológicos. Por isso, se aquilo está recolhido, deve- se a a EDP. nptpub-742\#\# Quando os protestos eclodiram, os media internacionais divulgaram para todo o mundo informações sobre uma carnificina em larga escala de a população revoltada de a cidade por as forças fiéis a Ceausescu. Estas notícias alarmistas em um relatório recente, os serviços secretos romenos acusaram espiões húngaros e de outras nacionalidades de terem incitado a a revolta contribuíram decisivamente para o derrube de o regime, mas mancharam a revolta. Afinal, os cadáveres nus e alinhados descobertos não eram vítimas de a repressão, mas antes de pessoas pobres, doentes e inválidas, exumadas de fossas comuns e colocadas em o local. Hoje, o monumento a os heróis desconhecidos de 1989 não faz qualquer alusão a este episódio e em o enorme talhão continua a ser enterrado quem não pode pagar uma sepultura decente. Estávamos em estado de choque, vítimas de uma alucinação colectiva. Vi o cadáver de uma mulher com o seu filho em o ventre. Eram (CP Séc. XX: 19N:Pt:Público)

d) afinal 4 (marcador discursivo): na função de marcador é identificado em questionamento, podendo ocorrer no início, meio ou final da pergunta.

(28) ... se avistar com Suharto em Jacarta. Preocupação internacional Os Eua, a Austrália e o Canadá manifestaram a as autoridades indonésias a sua preocupação a propósito de o assassinato de seis timorenses em o mês passado. npt-pub-7694\#\# Em o meu primeiro ano de faculdade, fiz um trabalho sobre os dois anos de televisão privada em Portugal. A SIC era em a altura o canal preferido de todos os portugueses. Ainda assim é, mas se fosse hoje fazer o inquérito que levei a cabo em a altura, com certeza que as respostas seriam contrárias, e falsas!! Afinal, a SIC é ou não líder de audiências em Portugal? Os factos confirmam- no. Ora deixemos- nos de falsas cumplicidades e ataques constantes de cinismo, admitamos que nos deliciamos com os Big Show SIC e os All You Need Is Love, essa é a realidade de o sistema, de o povo português. Não quero aqui salientar exacerbadamente o meu pesar e tristeza por a estratégia de a SIC, pois, como estudante de comunicação e futura jornalista pretendo vir a ser, é realmente chocante ver posta (CP Séc. XX: 19N:Pt:Público) 


\section{Padrões funcionais da palavra afinal no PB}

Para verificar os padrões funcionais no PB, também consideramos o período do século XX e identificamos:

a) a final 1: também trata-se de adjetivo recategorizado em substantivo devido à elipse do substantivo "partida" (por metonímia), que por sua vez resulta em lexicalização.

(29) infernal fez com que eu levasse nada menos que 20 minutos de minha casa até aqui. Isso que eu moro no centro da cidade, mas tudo bem. Mau humor à parte, assim que me acomodo no estilo Marília Gabriela, cara a cara com o computador, o telefone entra em ação. Para alegria minha, já que as atividades do golfe paranaense estão congeladas até o próximo mês, era o Roberto Barrionuevo, Barriquinha como é chamado pelos amigos, o secretário executivo da Federação Paranaense de Golfe, contando as news da entidade. Ele confirmou a final do Interclubes do Paraná para os dias 9 e 10 de agosto em Foz do Iguaçu. Concluindo, garantiu as presenças de Rodrigo Diniz e Ivo Leão nos jogos do Campeonato Brasileiro Amador, a ser realizado de 24 a 27 de julho no São Fernando Golf Club, em São Paulo. Em seguida, com o " calundu " ainda à flor da pele (me permitam aqui o parêntese, mas até consegui rir, pois lembrei de uma grande amiga, cujo estado citado acima - calundu - é uma (CP Séc. XX 19N:Br:Cur)

b) afinal 2 (advérbio): o afinal determina uma finalização, podendo ser anafórico, já que retoma contexto anterior e apresenta uma conclusão finalizadora das ideias já expressas no texto.

(30) lá embaixo, faixas e cartazes alusivos ao movimento. Era preciso apressar-se e redigir o despacho, uma vez que, naquele instante, outras agências recebiam a mesma nota e, de um mo-mento para outro, as estações de rádio entrariam 
no ar com o comunicado da Confederação. Cod chamou um operador de telex e, aqui e ali consultando-a sobre detalhes, emitiu diretamente para Nova Iorque uma correspondência especial, que seria manchete em todos os noticiários do mundo. Prometendo comunicar-se com ele para uma entrevista com seu pai e outros líderes da causa, Lina conseguiu, afinal, descer à rua. Estava em jejum natural e procurou fazer uma merenda no balcão de um café, onde se vendiam pastéis, quibes e outras comidas árabes, antes de retornar ao bureau. Foi ali que encontrou Samuel Brusky, a quem confiou sua preocupação com o desaparecimento de Edu. Samuel não procurou disfarçar a gravidade do fato: - Se você não tem dúvidas sobre a lealdade de Edu (você é quem sabe), essa ausência é muito séria. Porque também o Evaristo está sumido.. -(CP Séc XX 19:Fic:Br:Beltrao:Greve)

c) afinal 3 (operador argumentativo): Pode ser parafraseado por 'pois', o que denota seu caráter explicativo, também validando um raciocínio conclusivo.

(31) perdendo alguma coisa. - A Bia deve estar enchendo a tua cabeça com essas merdas. - Não é só ela, é quase todo mundo. Repara. - Eu tenho mais o que fazer - disse Beny, fixando os olhos num adolescente que entrava carregando uma coroa de flores " Um boy de floricultura ", pensou encantado. - Eu estou com vontade de me dedicar ao estudo de fenômenos parapsicológicos. Talvez introduza no livro um capítulo sobre esse tema. Beny não escutava o que ele estava dizendo. Acompanhava interessado todos os movimentos do garoto. Afinal um livro tem que refletir o seu tempo - continuou Adônis - Não é isso que se costuma dizer? - Não sei - disse Beny, precipitando-se atrás do rapaz tão logo ele se encaminhou para a saída. Adônis só compreendeu o que estava acontecendo quando, pouco depois, olhando para fora, viu Beny e o menino parlamentando junto à banca de jornais " Então era nisso que ele estava interessado ", pensou. No momento seguinte, Beny abria a carteira e colocava algumas notas na mão do rapaz (CP Séc. XX 19:Fic:Br:Amaral:Amigos) 
d) afinal 4 (marcador discursivo): na função de marcador é identificado em questionamento, podendo ocorrer no início, meio ou final da pergunta.

(32) reeleição ele conseguiria unificar sua base de sustentação e com isso viabilizar com mais facilidade as reformas, mas o objetivo maior são as reformas. A reeleição é um problema complicado porque envolve interesses pessoais, corporativistas, mas o instituto da reeleição é altamente sadio. O plebiscito seria somente perda de tempo e gasto de dinheiro. Qual o plebiscito mais efetivo que o dia da eleição? OP - Ainda em relação ao FEF, alguns parlamentares de oposição dizem que este dinheiro vai para pagamento da dívida interna brasileira, e não para programas sociais como educação, saúde. Afinal, onde é empregado o recurso? NO - Isso é dialético. Na realidade, o Tesouro é um só. Com o dinheiro do FEF, o Governo tem um saldo de caixa que pode viabilizar ações sem ter que recorrer a aumento da dívida. O FEF está viabilizando alguns programas. Por exemplo, a CPMF, que passou um ano para ser aprovada e que é destinada exclusivamente para saúde, não acrescentou quase nada porque, anteriormente, o Tesouro, face à dificuldade de receita para a saúde (CP Séc. XX: 19Or:Br:Intrv:Pov)

(33) não sabe o que está dizendo, Lena? - Bia protestou. Você não sabe o que é a passagem para um suicida, você não tem idéia do que é um retrocesso espiritual. O Leo vai vagar anos e anos pelas trevas. - Isso é bobagem! Quem vai sofrer somos nós que vivemos nesta merda de país! Somos nós que estamos envelhecendo e que não vamos sequer ter o conforto de uma aposentadoria porque os ladrões do governo já levaram tudo que é nosso! Raquel parou diante da entrada e esperou que Lena acabasse de falar. - Afinal isto é um velório ou um comício? - perguntou. - Vá por inferno! - disse Lena. - Parece que você não perdeu a mania de fazer discurso. - Não era discurso, era só uma opinião exaltada. -Me diga uma coisa, Adônis. O que você acha 
realmente do suicídio do Leo? Depressão profunda, surto paranóico, exibicionismo? - indagou Beny. -Por que não pergunta à Lúcia? Ela é a especialista na matéria, não eu - respondeu Adônis. - Eu não (CP Séc. XX:Fic:Br:Amaral:Amigos)

\section{Contraste entre variedades}

Após analisar no corpus que foi constituído para esta pesquisa, dados do século XX, conforme vimos nas seções 1 e 2 deste mesmo capítulo, tanto no PP quanto no PB ocorrem os mesmos padrões funcionais. Contudo, percebemos que os dados só desse período, não seriam suficientes para justificarmos as intuições que até o momento tínhamos para compreender as similaridades e diferenças do item sob análise. Então, também direcionamos nosso olhar para o período dos séculos XVII ao XIX.

Procuramos a palavra afinal e $\boldsymbol{a}$ final $^{11}$ no século XVII, contudo não surgiram ocorrências. Rumo ao século XVIII, localizamos apenas duas ocorrências no PP; no século XIX, identificamos um total de 16 ocorrências da forma a final no PP, ainda neste período, para a forma afinal, selecionamos para análise 50 ocorrências para o PP e mais 50 para o PB, já que havia uma grande número de dados para cada uma das variedades.

\begin{tabular}{|l|c|c|c|c|}
\hline Século & PE - a final & PE - afinal & PB - a final & PB - afinal \\
\hline XVII & $\varnothing$ & $\varnothing$ & $\varnothing$ & $\varnothing$ \\
\hline
\end{tabular}

${ }^{11}$ Consideramos pertinente também verificar a forma a final, em virtude das informações que tínhamos dos dicionários consultados para esta pesquisa. 


\begin{tabular}{|l|c|c|c|c|}
\hline XVIII & 2 & $\varnothing$ & $\varnothing$ & $\varnothing$ \\
\hline XIX & 16 & 50 & $\varnothing$ & 50 \\
\hline XX & 50 & 50 & 50 & 50 \\
\hline
\end{tabular}

Quadro 3: Resumo do número de dados analisados do século XVII ao XIX

Por este quadro, é possível notarmos, com base no corpus que analisamos,que a forma a final, que é única no século XVIII; no XIX, apresenta menor frequência de uso comparado a nova forma (afinal) do mesmo período.

Destacamos que no século XX, conforme vimos os padrões funcionais do PP e $\mathrm{PB}$, as duas formas ( afinal e a final) estão difundidas com seus usos diferenciados nos dois países.

Nos exemplos abaixo também podemos verificar que o fenômeno se apresenta em estruturas sintáticas semelhantes no PP e PB. Tomemos por base o exemplo (34) do PP e o (35) do PB, nos dois casos a expressão a final traz em sua carga semântica a ideia da palavra partida e a presença do SN posposto ao termo tem caráter de uma maior especificação, mas a sua ausência não permitiria inteligibilidade do contexto.

(34) ..., ontem, uma vitória histórica para o ténis nacional, ao vencer $\boldsymbol{a}$ final de pares do Maia Open/Oporto Cup, derrotando o par australiano, Josh EagleAndrew Florent ... [52] (CP do Séc XXN:Pt:Jornal)

(35) ...imediatamente inferior a os profissionais em um time de futebol. Apesar de perder $\boldsymbol{a}$ final de o torneio em o tempo normal por 4 a 2 para o Guarani, ... [53] (CP do Séc XX N:Br:Folha) 
Ainda se referindo à estrutura sintática, no exemplo (36) do PP e (37) do PB, percebemos mais uma similaridade, a palavra afinal pode atuar no texto introduzindo um tópico, dando encaminhamento e fechamento. No caso do primeiro, organiza e relaciona tópicos anteriores; é característico, também, apresentar-se em proposições afirmativas, o que evidencia a necessidade do locutor por uma resposta breve e objetiva. No segundo - dando encaminhamento - estabelece uma relação coesiva entre proposições de um mesmo tópico. Por último - fechamento - aponta para a conclusão de um tópico de modo resumitivo ao que foi argumentado em tópicos anteriores.

(36) das outras, Escher convida-nos a seguir o percurso das serpentes e a verificar que os três répteis estão alinhados num percurso único, apesar de parecerem seguir duas órbitas distintas. Na segunda dessas gravuras, em que nove formigas se passeiam, caminhando sempre no mesmo sentido, Escher desafia-nos a seguir o seu percurso e verificar que é um percurso sem fim, pois de onde quer que se parta volta-se sempre ao mesmo lugar. As formigas passeiam-se, ao que parece, em dois lados diferentes de uma superfície, mas cada uma delas percorre, afinal, toda a superfície em que se passeia. Tanto numa como noutra gravura, o caminho não tem fim. É muito fácil construir um modelo de tira de Möbius. Corte-se uma tira de papel, dêse meia volta numa das pontas e cole-se essa extremidade à extremidade oposta. Surpreendentemente, a superfície resultante tem apenas uma face: tomando quaisquer dois pontos na tira, mesmo que, aparentemente, em lados opostos, é possível chegar de um ponto ao outro, sempre ao longo da superfície e sem cruzar a aresta. É (CP do Séc XX Ac:Pt:Enc)

(37) Estado - fica na Espanha?

Benedetti - Não tenho data para regressar, devo viajar até quase o fim do ano. Em fins de outubro, por exemplo, tenho um compromisso na Grécia, 
onde meus livros começam a ser traduzidos. Bem, estou traduzido em 25 idiomas e tenho mais de 70 livros, então é natural que apareçam sempre convites de todos os lados.

Estado - Sua obra é sempre associada à sua vasta militância política. Do alto de seus 76 anos, o sr. se definiria como um escritor político?

Benedetti - Não posso negar, afinal tenho muitos livros que estão aí como prova disso. Mas, em geral, colocam-me essa etiqueta como algo desqualificador, é uma maneira sutil de tentar diminuir o valor de minha obra e então eu não posso aceitar. Se alguém ler com atenção todos os meus 70 livros verá que me ocupo, sobretudo, do amor e dos temas filosóficos. Deles, só 8 ou 9 podem ser considerados textos políticos.

Estado - O sr. viveu exilado em Cuba e sempre teve laços muito fortes com o regime (CP Séc. XX 19Or:Br:Intrv:ISP)

Retomemos o século XVIII, neste período o item sob análise foi identificado somente no PP em um contexto religioso. Neste caso, o substantivo feminino elíptico só pode ser identificado porque a expressão a final faz referência ao que já foi mencionado. Verifiquemos os exemplos (38) e (39), no primeiro, a final faz referência ao termo causa, o que nos faz entender que a ideia expressada é de que a última causa foi o culto a Deus. No segundo, o termo em elipse é a cousa. Nos dois casos, além de ter sido necessário o termo elíptico ser mencionado anteriormente, também é importante notar que em ambos o item $\boldsymbol{a}$ final é utilizado para mostrar o último evento, já dando indícios de sua marca de finalização e conclusão de um evento como acontece no século $\mathrm{XX}$, não só no $\mathrm{PP}$, mas também no $\mathrm{PB}$, conforme evidenciamos nos padrões funcionais do afinal 2, afinal 3 e afinal 4. 
(38) Os Oradores tambem reduzem às causas a occasiaõ, e pretexto comque a cousa se faz. Porque o pretexto he huma causa fingida, e apparente. O modo de argumentar pelas causas he este. Queremos celebrar v. g. o famoso Templo de Jerusalem? olhemos para as suas causas, e nellas acharemos o melhor argumento do seu louvor. Porque a efficiente foy Salamaõ, Rey sapientissimo, e riquissimo: a materia foraõ pedras preciosas, madeiras de cedro, e muito ouro: a formal foy a bela arquitectura, e forma do templo: $\underline{\boldsymbol{a} \text { final }}$ foy o culto, e veneração de Deos. Queremos reprehender v. g. o Homem vicioso, e perdido olhemos para as suas causas, e nellas acharemos o melhor meyo para a nossa invectiva. Diremos ser cousa indigna, e torpissima, que viva como bruto entregue aos appetites, quem he dotado de huma alma racional, creada à semelhança de Deos: eis aqui a causa formal. Diremos, ser contra toda a razaõ, deixarse arrastar do amor das creaturas, quem foy creado para ver o ...(CP Séc. XVIII: 17:Pereira:Elementos)

(39) ...- (23) que se o naõ reprimira a Fè, a tivera por Deos. 4. Assim o persuade a razaõ de Aristoteles, (24) que ensina, que a obra perfeyta procede de quatro cousas: material, efficiente, formal, \& final. Na Virgem foy material a nobreza do sangue, de que por razoens naturaes, procede ordinariamente disposição gentil; (25) a efficiente foy a mão Divina por modo especialissimo em sua Conceyçaõ; (26) a formal, sua alma gloriosa, que devia vestirse de corpo que a merecesse; $\underline{\boldsymbol{a} \text { final }}$, haver de nascer della o Filho de Deos com semelhança de Filho, como em effeyto se pareceo Christo com ella. (27) 5. Mais em particular pelo que de vista testemumháraõ S. Dionysio, \& Santo Ignacio, \& deyxáraõ escrito Authores Hebreos, \& Gregos daquelles tempos, fez descripçaõ exacta da fórma Divina, \& feyções da Virgem Epifanio (28) Presbytero de Constantino- pla, muyto versado nas historias, \& letras Gregas, \& Hebraicas, a quem seguiu o antigo Niceforo, \& ... (CP Séc. XVIII:Macedo:EvaAve).

No século XIX, segundo mostrou o corpus analisado, enquanto em Portugal coocorrem as formas afinal e $\boldsymbol{a}$ final sem distinção de significado, no Brasil há 
ocorrências apenas com afinal. Por fim só no século XX é que temos nos dois países as duas formas ( afinal e a final ), sendo utilizadas distintivamente entre elas, mas não entre as nações. 


\section{Capítulo V - Proposta de diálogo com o ensino}

Inspirados no trabalho desenvolvido por Sartin (2008), que buscou um diálogo entre gramaticalização e ensino, perguntamo-nos se:

a) os professores perceberiam a diferença entre os usos dos padrões funcionais do item afinal.

b) os professores teriam consciência das diferenças de estatuto entre os padrões funcionais do item afinal.

c) as diferenças entre os padrões funcionais, principalmente aquele voltado para a função textual (de modo especial nos momentos de ensinamento voltado para a produção de textos dissertativos), seriam tratadas pelos autores de livros didáticos destinados aos ensinos fundamental e médio.

No trabalho de Sartin (2008), a autora reconheceu que a estrutura para + verbo era categoricamente tratada - tanto por professores quanto pelos autores de livros didáticos - como orações reduzidas de infinitivo com valor de finalidade. Após levantar os dados pertinentes ao corpus com que trabalhou, a autora percebeu que a finalidade não se mostrava a função mais recorrente.

Depois de identificar os padrões funcionais, providenciou dois testes: a alunos de escola básica (ensinos fundamental e médio) e a professores de português. Os resultados ratificaram o que havia intuído: os professores replicam o conteúdo da gramática sem refletir sobre o conhecimento que transmite. O resultado é que os alunos não conseguem lidar com os rótulos gramaticais porque os dados analisados pela escola 
(sob influência da normatividade) remetem a funções diferentes das reais que se percebem nos usos.

Considerando que o item afinal também parece representar essa "unanimidade" de conceitos entre os professores, imaginamos que um teste seria capaz de nos fornecer elementos importantes para propor um diálogo com a escola, no que se refere especificamente ao ensino de português.

Para dar conta de nossos propósitos, procedemos a uma amostra de livros didáticos e também elaboramos testes que foram respondidos por professores responsáveis pelo ensino de língua portuguesa.

\section{A situação no livro didático}

Para essa empreitada, selecionamos os seguintes materiais didáticos:

1. MAROTE, João Teodoro D’olim. Português funcional. São Paulo: Cia. Editora Nacional, 1972 (volume 2 - 6a série);

2. FARACO, Carlos Emílio; MOURA, Francisco Marto de. Gramática. São Paulo: Ática, 1992. (sem série definida);

3. MAIA, João Domingues. Português (ensino médio). São Paulo: Ática, 2002.

Marote (1972: 167) situa a palavra afinal dentre os advérbios de tempo:

A)Advérbios: 
- de tempo: agora, afinal, ainda, amanhã, anteontem, anteriormente, antes, breve, brevemente, cedo, depois, diariamente, então, hoje, já, jamais, logo, mensalmente, nunca, ontem, outrora, raramente, sempre, tarde, etc.;

A NGB, contudo, abre uma brecha para que os gramáticos possam incluir numa categoria "residual" tudo o que não cabe bem e de modo perfeito nas dez classes de palavras. Trata-se das "palavras denotativas". Notemos que o item é categorizado como advérbio de tempo. Seguimos consultando um outro material, desta vez elaborado por Faraco \& Moura (1992:284) que lançam mão desse rótulo para classificar algumas palavras, dentre as quais está o item afinal:

\section{PALAVRAS E LOCUÇÕES DENOTATIVAS}

Algumas palavras e locuções, que eram consideradas advérbios, na verdade não se enquadram em nenhuma das dez classes gramaticais.

A NGB faz uma classificação à parte dessas palavras e locuções chamando-as de palavras denotativas. Tais palavras e locuções denotam:

$(\ldots)$

g. situação: afinal, agora, então, etc.

afinal o que queríamos? (C.Lispector)

Então, o senhor ia ser diplomata. (Senhor) 
Notemos, inicialmente, que pelo menos vinte anos separam Marote de Faraco \& Moura. Mais do que equívoco de classificação, preferimos acreditar que se os autores se refeririam a tipos de padrões funcionais distintos. O primeiro deveria se referir a um elemento que denotasse um ponto final na linha de tempo de desenvolvimento de uma ação/evento, enquanto os últimos estão a se referir a um elemento que está a serviço do discurso.

Cada um desses materiais parece focalizar um padrão funcional diferente. A distância temporal entre Faraco \& Moura (1992) e Maia (2002) parece ser bem menor. Talvez isso justifique o fato de se referirem ao mesmo tipo de uso (provavelmente o mais recorrente) em seus exemplos. Maia (2002:264-5), a exemplo dos anteriores, preferirá manter o item dentre as palavras denotadoras de situação.

\section{Palavras e locuções denotativas}

Certas palavras ou locuções, que não se enquadram em nenhuma das classes de palavras recebem o nome de palavras ou locuções denotativas. Para reconhecê-las, é preciso observar o sentido da oração. As principais são:

f) de situação: mas, afinal, agora, então etc.: afinal, quem é ele?

Outros livros consultados não apresentaram nenhuma referência ao item sob análise. Os que trazem deixam entrever que houve um deslizamento funcional de afinal, mas que os autores não atentam para o fato de que há mais de um emprego implicado e que mereceria alguma orientação, comentário que provocasse a reflexão do aluno. Essa 
reflexão seria um gatilho necessário para que o dito em sala de aula fizesse todo sentido para o aluno, usuário proficiente da língua portuguesa.

Numa análise superficial, podemos afirmar que o que parece importar mais ao autor de livro didático quando prioriza um tema para discussão é o fato de esse tema “estar ou não dentro da NGB”.

Outra possibilidade de explicação para o tratamento raso dos temas complexos em livros didáticos seria proporcionar a facilidade de compreensão ao aluno. No entanto, para atingir a esse objetivo, descrevem alguns padrões priorizados aleatoriamente e deixam de fora outros que estão mais próximos do cotidiano do aluno. O contexto de emprego parece ainda não importar para o livro didático, tal como ocorria no passado quando exemplos não eram necessários (tal como apresentado por Marote).

Há uma tendência atual de se entregar ao professor um livro contendo orientação de abordagem e também as respostas dos exercícios. Convencionou-se chamar esse material de "livro do professor".

Não é raro encontrarmos no livro do professor a informação de que o livro didático apresenta uma proposta inovadora de ensino de gramática. Quando, no entanto, avaliamos um dos capítulos, notamos que, na prática, não há uma contribuição tão inovadora assim. Os materiais continuam adiando a tarefa de dialogar com o aluno, de provocar reflexão sobre a língua em uso.

O resultado é que as dúvidas dos professores têm se proliferado e as dos alunos sequer podem ser manifestadas. Esses materiais, além de não esclarecerem, trazem uma lista de palavras que são classificadas como advérbio, e que, certamente, nosso aluno 
tentará resolver da forma mais primitiva na escola: decorar para acertar. Resolverá seus exercícios devolvendo na íntegra o conteúdo apresentado, mas não será capaz de transferir esse conteúdo para aplicações diversas.

Ao tentar refletir sobre os dados mais complexos ou até mesmo, podemos dizer, dados recorrentes de uma língua dinâmica (que se renova e se modifica para satisfazer a necessidade do falante), nosso aluno certamente terá muitas dúvidas em compreender o que ocorre, pois a realidade do uso não coincide com o que é ensinado na escola. No caso do ensino médio, essa é uma inadequação ainda mais cruel, pois todo o ensino médio é voltado para um único objetivo: aprender para passar no vestibular.

Retomemos o exemplo oferecido por Maia (2002): “afinal que é ele?”. Questionamos quanto a que tipo de situação o autor se reportaria e perguntamos: por que não explicitar um contexto mais amplo ao aluno?

Acreditamos que os estudos funcionalistas vieram para dar uma grande contribuição para o ensino da gramática, pois permitem uma concepção de gramática mais reflexiva, que trata o professor e o aluno como o que de fato são: indivíduos reflexivos, capazes de entender fenômenos linguísticos contextualizados na situação de uso. A complexidade de uma forma manifestada em muitos padrões funcionais não se torna menos complexa com o tratamento raso normativista.

Acreditamos que essa falta de convergência e de propósito descritivo possa se refletir nas buscas de caminhos empreendidas por professores para resolver problemas linguísticos, porque foram treinados nesse modelo e o põem em prática dia após dia. 


\section{Um teste sobre os usos e reconhecimento de funções}

Depois de analisarmos o estatuto do item afinal no PB e de compararmos com os padrões funcionais do PP, optamos por aplicar dois testes a professores de língua portuguesa. Com esses testes, teríamos condições de verificar a hipótese de que o ensino normativo bloqueia a reflexão sobre o fato real apresentado ao professor.

O primeiro teste foi constituído de oito fragmentos de textos de que foi retirada a palavra afinal. Em seu lugar, foi deixada uma lacuna para que o informante pudesse completar do modo que considerasse mais adequado.

O segundo teste foi composto por dez fragmentos de texto em que a palavra afinal viria destacada. A proposta é que o professor categorizasse o item afinal livremente. Hipotetizamos que o professor tentará se manter dentro das dez classes de palavras, mesmo que o emprego apresentado não tenha ali guarida.

Selecionamos, então, o grupo de informantes para participar dos testes e chegamos ao seguinte perfil: 13 pessoas com graduação em Letras e que atualmente cursam a disciplina de pós-graduação (mestrado ou doutorado) na área de Língua Portuguesa.

Das 13 pessoas que responderam ao teste $\mathbf{1}$, apenas quatro não tinham experiência no magistério; as demais já atuavam no magistério com experiência de um a vinte e um anos. 
A faixa de idade desse público, dada a experiência em magistério, também era diversificada: de 22 a 58 anos, havendo onze pessoas do sexo feminino e somente uma do sexo masculino. Um dos possíveis informantes se recusou a preencher os campos referentes à idade e ao sexo. O público do teste 2 foi praticamente o mesmo. A diferença ficou por conta de uma informante que se recusou a respondê-lo.

Para compor o teste, incluímos dados da expressão 'a final', pois acreditávamos que a classificação de artigo + substantivo também evidenciaria o ‘esquecimento histórico' a que se referiram Lima-Hernandes (2008) e Defendi (2008). Tendo em vista que o sintagma nominal a final já traz em sua carga semântica o sentido de partida, competição, prova e etc., então não mais enxergarão o adjetivo final como modificador de um item elidido.

Aplicado o teste 1, verificamos que a lacuna preenchida permitiu confirmar as paráfrases que propusemos nos padrões funcionais descritos, ao mesmo tempo em que puderam explicitar outros valores que, embora não tivessem sido citados, mantiveram traços de conclusão ou finalização.Segue abaixo o teste 1:

1) O Lacio continha o territorio dos Latinos, dos Volscos, dos Equos, dos Auruncos ou Ausonios, e dos Hernicos; o que se diz hoje a campanha de Roma. Nomeava-se paiz do Tibre o que hoje he a Toscana. Laurento he agora São Lourenço. - sobre o assento desta cidade, escreve Mr. Bonstetten, mudei tres vezes de parecer, e __ achei-o um pouco acima do Laurentum de Plinio, para junto das collinas de Decimo, á pequena distancia do pantano. (18:Mendes:Eneida4)

2) Por isso sômos de parecer, que ao menos no principio do exercicio da prégação, o Orador escreva todo o seu discurso o mais perfeitamente, que o podér fazer; o que será utilissimo até para chegar a adquirir a facilidade, e o habito da correcção, tanto da parte da linguagem, como dos pensamentos, mais que tudo tratando de assumptos rigorosamente pertencentes á Religião: sendo que esta mesma pratica será da maior utilidade não só para o principio, como ainda para a continuação do exercicio do Pulpito. REGRA XI. §. 16. Observaremos que o uso de ler os sermões, em vez de os declamar de cór, o qual se acha em vóga em alguns paizes, é provavelmente um dos grandes obstaculos para se conseguirem os fins deste Genero de eloquencia; (18:Carvalho:Lições) 
3) O Cruzeiro vive um momento decisivo: precisa vencer no Brasileiro pois está mal colocado e decide quarta-feira no Chile contra o Colo Colo a sua classificação para da Libertadores. (19N:Br:Cur)

4) As semifinais serão disputadas nos dias 9 e 23 de abril, também em jogos de ida e volta. jogo (19N:Br:SCat) está marcada para o dia 28 de maio, em Munique, Alemanha, em um único

5) Aquêle estranho cortejo de macacos com fardas e de mulheres com farrapos, de carros de flores e berlindas d' entrudo, e vendedores de boquilhas e professoras d' instrução primá- [2O3.1] ria, de bombeiros d' Ajuda e de meninos enjeitados contentes todos, mirando-se, larachando, detendo-se a comprar pastelinhos, a altercar com os cocheiros a fazer adeusinho às relações; aquêle cortejo que representa? Ninguém o soube. (18:Almeida:Gatos1)

6) Propõe-se ao Sr. Franco Castelo Branco uma Régie do amor barato - Mil e quinhentos casos de hidrofobia, e imunidades sociais do cão -Cães ricos e parentes pobres - Quem é o rei dos animais? -Os três amores da (18:Almeida:Gatos2)

7) OP - Ainda em relação ao FEF, alguns parlamentares de oposição dizem que este dinheiro vai para pagamento da dívida interna brasileira, e não para programas sociais como educação, saúde. , onde é empregado o recurso? (190r:Br:Intrv:Pov)

8) já nasceu proprietário da generosa fortuna pertencente à mãe plebéia; existe gente de sorte, igual ao neto a ele, ambos ganhando a vida com o dinheiro da defunta, o dinheiro e o trabalho pois Sofia ainda lutava; vida morna e dengosa, como, , vivem os nobres, não combinava com ela, tomava o destino nas mãos, tomara que o fidalguinho tenha lhe herdado a força, casar-se-á com princesa e não fará muita coisa, Sofia fez muito mais.

Dos 08 fragmentos do primeiro teste, esperávamos que tivéssemos nossa análise ratificada se as lacunas fossem preenchidas com: operadores argumentativos para 1 e 2, artigo e substantivo para 3 e 4, marcadores discursivos para 5, 6 e 7 e advérbios com marcas conclusivas em 8 .

Os resultados aferidos foram os seguintes:

a) Fragmentos 1 e 2: $77 \%$ das expressões que preenchiam as lacunas atuando como operadores argumentativos anafóricos, já que retomam fazendo o encerramento de fatos/eventos sequenciados no texto, o que caracterizaria seu traço conclusivo. As expressões são as seguintes: por fim, cheguei à conclusão, afinal, na minhas buscas, enfim, finalmente, com isso, mesmo assim, junto aos 
seminaristas, por sua vez, portanto, desse modo e então . Houve também duas pessoas que optaram pela expressão agora, e uma pessoa não preencheu a lacuna por entender que o texto é inteligível sem qualquer outra expressão naquela lacuna.

b) Fragmentos 3 e 4: $81 \%$ dos informantes inseriram na lacuna expressões associadas a jogos, esportes, especialmente remetendo a futebol: a copa, copa, as semi-finais, as oitavas-de-final, a vaga, a final, a disputa final; para $19 \%$ dos informantes, seria necessário adotar estratégias de inclusão verbal (tal como o verbo participar) e de pronomes relativos (que, a qual).

c) Fragmentos 5, 6 e 7: os informantes optaram pela inserção das seguintes expressões adjetivas, adverbiais, artigos definidos: supracitado, inusitado o, afinal, ali, estranho, o que será, o, todo, de indigentes o, afinal, afinal de contas, então, que é, o leão, aquele, realmente, agora, portanto, enfim, na verdade, ou seja, citado anteriormente, de fato. A variedade de opções reforça a ideia de que afinal é um marcador discursivo, pois, sendo esvaziado de seu sentido original, não imporia restrições a outras expressões de sentidos variados.

d) Fragmento 8: 50\% dos informantes preencheram a lacuna com advérbios que passavam uma ideia conclusiva: até hoje, também, atualmente, afinal, de fato e ainda; os outros $50 \%$ foram desconsiderados, pois tratavam-se de escolhas lexicais que não mantinham a coerência do texto (igual, morrera, contudo, rei e rainha, fielmente).

Mais do que incoerência dos cinquenta por cento que deram respostas inesperadas, podemos dizer que são os professores que buscaram uma resposta mais próxima da normativa e não encontraram saída. 
O teste 2 foi formulado com vistas à busca de respostas sobre a categorização linguística. A ideia era que afinal seria mais recorrentemente classificado à luz das dez classes de palavras e não à luz da função propriamente desempenhada no trecho apresentado. No que se refere ao item final, queríamos saber se o informante ainda teria em mente a ideia de adjetivo recategorizado como substantivo.Segue abaixo o teste 2.

Teste 2: Classifique morfologicamente a(s) palavra(s) destacadas:

1) Toda eleição é difícil, mas o importante é que lancemos candidato próprio, afinal, o PMDB é muito forte, até no contexto nacional. (190r:Br:Intrv:Pov)

2) A grande exceção são os cursos para as áreas de escritório (secretariado, administração de pequenos negócios, contabilidade, etc). Esses são cursos com afinidades para o ensino acadêmico. Dao-se bem dentro das escolas regulares. Afinal, aprender a usar um computador é cultura geral ou profissional? (190r:Br:Intrv:ISP)

3) Meu tema está acima de qualquer suspeita: a nostalgia do amor, sempre. Estado - São 45 anos de comparação com Beckett, Kafka, Dostoievski, Ionesco, Valle Inclán - com quem afinal você se identifica?( 19Or:Br:Intrv:ISP)

4) Por exemplo, o Oscarito ganhava 3 mil e o Grande Otelo, 1.500. Mas firmei o pé. Se na revista eu faturava no mínimo 13 mil não iria por menos disso. Afinal, já era casado e pai de dois filhos. Tinha obrigações e eles acabaram concordando. Comecei a fazer uma série de filmes, como Pinguinho de Gente, Terra Violenta...( 19Or:Br:Intrv:ISP)

5) Como você chegou até o topo? Afinal, vender um primeiro livro por tal fortuna não é para qualquer um. (190r:Br:Intrv:ISP)

6) O jogador decidiu que não permaneceria em o Barcelona quando não foi escalado por Cruyff em a partida semifinal de a Copa dos Campeões, contra o Porto. Em a final, quando o Milan goleou o Barcelona por 4 a 0 , Laudrup ficou novamente de fora e confirmou sua decisão de sair. (19N:Br:Folha) 


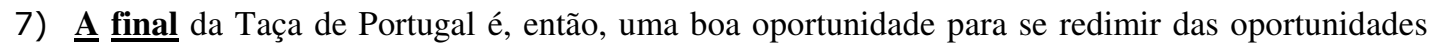
não concretizadas no jogo do campeonato? (19Or:Pt:Intrv:Jrnl)

8) Nomeava-se paiz do Tibre o que hoje he a Toscana. Laurento he agora São Lourenço. - sobre o assento desta cidade, escreve Mr. Bonstetten, mudei tres vezes de parecer, e a final achei-o um pouco acima do Laurentum de Plinio, para junto das collinas de Decimo, á pequena distancia do pantano.

9) A retirada de Turno, depois de se têr mostrado um Achilles, he descripta superiormente: o simile com o leão que, perseguido pelos monteiros, vai recuando lentamente, sem querer fugir, pinta o brio do rei dos Rutulos. A final, acossado pela multidão e por Mnestheu, lança-se ao rio e salvase a nado, com todas as suas armas. (18:Mendes:Eneida12)

10) Os Oradores tambem reduzem às causas a occasiaõ, e pretexto comque a cousa se faz. Porque o pretexto he huma causa fingida, e apparente. $\mathrm{O}$ modo de argumentar pelas causas he este. Queremos celebrar v. g. o famoso Templo de Jerusalem? olhemos para as suas causas, e nellas acharemos o melhor argumento do seu louvor. Porque a efficiente foy Salamaõ, Rey sapientissimo, e riquissimo: a materia foraõ pedras preciosas, madeiras de cedro, e muito ouro: a formal foy a bela arquitectura, e forma do templo: a final foy o culto, e veneraçaõ de Deos. Queremos reprehender v. g. o Homem vicioso, e perdido olhemos para as suas causas, e nellas acharemos o melhor meyo para a nossa invectiva. Diremos ser cousa indigna, e torpissima, que viva como bruto entregue aos appetites, quem he dotado de huma alma racional, creada à semelhança de Deos: eis aqui a causa formal.(17:Pereira:Elementos)

Passemos às respostas encontradas como solução ao teste 2, primeiramente com relação ao emprego do item afinal:

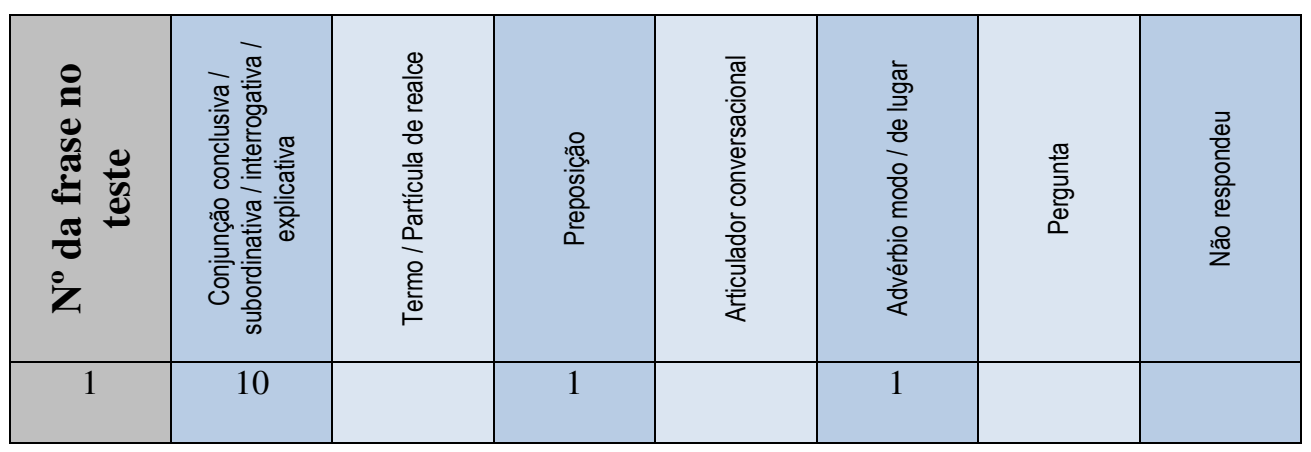




\begin{tabular}{|c|c|c|c|c|c|c|c|}
\hline 2 & 8 & & & & 2 & 1 & 1 \\
\hline 3 & 3 & 2 & 1 & 1 & 1 & 1 & 3 \\
\hline 4 & 9 & & & & 1 & 1 & 1 \\
\hline 5 & 8 & & & & 2 & 1 & 1 \\
\hline
\end{tabular}

Quadro 4: Resultado do teste 2 sobre a classificação gramatical da palavra afinal

Os resultados aferidos, no teste 2 para afinal, evidenciaram um número de escolhas muito significativas pela classe gramatical 'conjunção', isso confirma o caráter de operador argumentativo que o fenômeno estudado tem. A sentença 03 do teste, segundo nossa pesquisa trata-se de um marcador discursivo, contudo apenas um dos informantes optou por articulador conversacional, o que indica certa aproximação com nosso estudo, dado os articuladores conversacionais serem vazios de sentido. Ainda nessa sentença, a gama de respostas variadas, mostra a incerteza da classificação dada por nossos informantes.

Passemos ao quadro, em que é possível conferirmos os resultados da palavra $\boldsymbol{a}$ final:

\begin{tabular}{|c|c|c|c|c|c|c|c|c|c|c|c|}
\hline 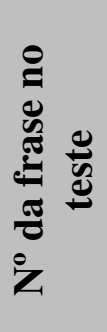 & 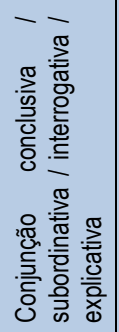 & 宸 & 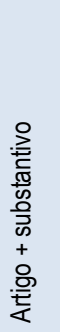 & 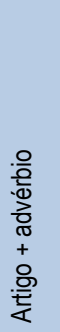 & 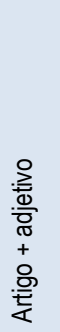 & 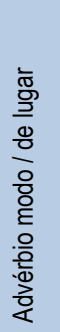 & 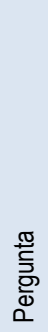 & 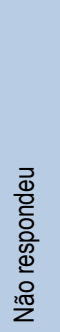 & 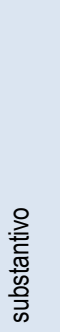 & 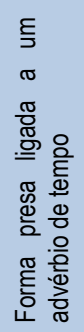 & 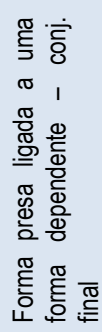 \\
\hline 6 & & & 4 & 1 & & 1 & & 1 & 5 & & \\
\hline 7 & & & 5 & 1 & & & & & 5 & 1 & \\
\hline 8 & 3 & & & 2 & & 2 & & 1 & 3 & & 1 \\
\hline 9 & 5 & & & 2 & & 2 & & 1 & 2 & & \\
\hline 10 & 2 & 1 & 2 & 1 & 1 & 3 & & 1 & 1 & & \\
\hline
\end{tabular}

Quadro 5: Resultado do teste 2 sobre a classificação gramatical da palavra a final 
No caso dos resultados aferidos para a final, atingiram nossas expectativas, pois já esperávamos que a escolha pela classe gramatical 'substantivo' fosse maioria. É possível observar no quadro 5, que escolha pela classificação 'substantivo' e ' artigo + substantivo', foi muito representativa comparada as outras classificações dados por alguns dos informantes. Isso comprova a recategorização de $\boldsymbol{a}$ final na função de substantivo.

Esses testes também provaram-nos como é grande a dificuldade de se classificar uma palavra, e mais, só podemos realmente fazer isso quando a contextualizamos, caso contrário podemos cair em uma classificação equivocada.

Também, chamaram-nos a atenção algumas nomenclaturas utilizadas pelos professores, tais como, conjunção conclusiva / interrogativa, ou ainda, conjunção explicativa / interrogativa; essas nomenclaturas apresenta a dificuldade que as pessoas têm na hora de classificar uma expressão. Isso também evidencia que a gramática normativa não da conta de permitir que as palavras sejam classificadas conforme sua função adequadamente. Desta forma, é natural que profissionais da língua tentem fazer isso, adequando as funções desempenhadas pelas palavras em determinado contexto, à terminologia da gramática normativa. Então, o resultado só pode ser uma mistura de conjunção conclusiva com interrogativa, ou classificações cercadas de ponto de interrogação, mostrando a dúvida deles na classificação do item afinal.

É importante mencionar que independentemente do tempo de magistério, nossos informantes buscaram o conhecimento que tinham de gramática normativa. Como nosso público que respondeu ao questionário tratou-se de pessoas com experiência de 1 a 20 anos de magistério, aponta que o ensino nas escolas tem sido o mesmo por diferentes 
décadas, ou seja, não se leva o aluno a uma reflexão da função das palavras nos diferentes contextos. 


\section{Considerações finais}

Esta pesquisa, amparada por pressupostos da gramaticalização de base funcionalista, teve o objetivo de investigar o comportamento do item afinal em sua trajetória de gramaticalização. No percurso da investigação, consideramos pertinente também tratar do esquecimento histórico implementado na expressão a final. Cada um deles representa nesta dissertação uma direção oposta de mudança linguística: lexicalização $\leftrightarrow$ gramaticalização.

No início da pesquisa, consultar os corpora de língua falada PEUL e NURC permitiu observarmos a tendência erudita do item. Essa observação foi depreendida de um conjunto de eventos, dentre os quais citamos o fato de que, no corpus do PEUL, apesar do número superior de entrevistas, a ocorrência de afinal foi ínfima. Já no corpus NURC, produzido por informantes exclusivamente de nível superior, encontramos um maior número de dados.

Ao considerar a etimologia apresentada em dicionários, mostramos que não havia consenso. Havia a indicação de que a palavra afinal formara-se de $a$ (preposição) + final, semelhantemente ao que ocorrera com o termo abaixo. O item final demonstrará um peso importante na rota de gramaticalização do item afinal, gerando padrões funcionais ligados ao ponto final de um percurso temporal e ao ponto final de uma ação mental. 
Do ponto de vista da categoria linguística, observamos um deslizamento funcional que parte de um advérbio associado a tempo, para um advérbio associado a situação final, passando a operador argumentativo.

No percurso do desenvolvimento desse estudo, deparamo-nos, já a partir do século XVIII com a expressão a final, compondo uma estrutura 'artigo + (substantivo elidido) + adjetivo', sendo que o adjetivo se referia a um substantivo mencionado anteriormente no texto, porém já era um indício de que mais tarde, no século XX, teríamos a estrutura 'artigo + substantivo', incorporando por mecanismos metonímicos o sentido do substantivo elidido.

Identificamos que o item sob análise, no século XIX, apresenta formas coocorrentes, afinal e a final, pois ambas contextualmente tinham funções idênticas. No século XX, cada uma delas ganha um novo sentido, iniciando, independentemente uma da outra, novas rotas: a primeira tende à gramaticalização e, a segunda, tende à lexicalização. Esses processos opostos só foram entendidos quando, seguindo nossas intuições acerca do item sob análise, decidimos realizar um estudo diacrônico. Somente a partir daí pudemos visualizar o que aconteceu com a palavra afinal, pois, como dissemos inicialmente, por se tratar de um item erudito, o processo de gramaticalização é mais lento e só em um período maior de tempo é que poderíamos entender as mudanças gramaticais.

O estudo diacrônico facilitou compreender a rota unidirecional de cada padrão funcional e assim vimos que as categorias [+concretas] são mais próximas da categoria processo e nas [-concretas] são mais próximas da categoria qualidade com funções textuais de operador argumentativo e de marcador discursivo. 
Identificamos seis padrões funcionais, contudo não descartamos a existência de outros que possam integrar algum tipo textual específico não priorizado nesta dissertação. Acreditamos que a melhor forma de reconhecê-los é estudando as situações de usos e os efeitos comunicativos, principalmente porque existem que não podem ser categorizados de forma discreta como uma categoria, mas que se difere dos demais padrões por perda de algum traço subjacente, que não se revela na superfície linguística.

Como marcador discursivo, no âmbito do tópico frasal, o item afinal destaca-se, de imediato, por não ser um elemento integrante da estrutura sentencial. Assumindo independência sintática em relação aos componentes da frase, revela não-integração à construção da sentença. Nesse contexto de uso, enquanto marcador, pode provocar a impressão de ser um elemento desnecessário e até mesmo descartável, como se sua ausência na sentença não causasse problemas do ponto de vista sintático e semântico, contudo percebemos que há uma grande perda comunicativa: a ênfase em um questionamento.

A palavra afinal, sintaticamente, tanto no PP quanto no PB pode atuar no texto introduzindo um tópico, dando encaminhamento e fechamento dos argumentos. Outra similaridade que identificamos, é quanto às duas variedades, $\mathrm{PP}$ e $\mathrm{PB}$, em ambas encontramos os mesmos padrões funcionais. Além disso, com base em nosso corpus de análise, os contexto em que foram identificados o fenômeno também eram similares; então acreditamos não ser possível ratificar a afirmação de que o PB é mais conservador que o PP.

Dada a necessidade de se mudar a maneira de conceber a gramática nas escolas, pensamos num capítulo em que travaríamos um diálogo ainda incipiente com o 
ensino/aprendizagem de língua portuguesa. Nesse capítulo, por meio de um levantamento de informações em livros didáticos, mostramos que os materiais não são capazes de provocar as reflexões e intuições dos alunos para resolver problemas. Estão mais voltados ao processo de decorar e devolver respostas simples mesmo que os problemas sejam complexos.

Os testes que desenvolvemos com professores demonstraram que um treinamento exclusivamente normativo impede a reflexão e a abordagem pedagógica voltada para a resolução de problemas. Os professores também não conseguem se desvencilhar das categorizações tradicionais para lidar com a evolução linguística. Com isso, consideramos que é preciso lidar com a consciência do aprender/ensinar e acreditamos que o funcionalismo linguístico pode fornecer as bases para essa mudança de concepção.

Numa gramática dinâmica, mesmo itens eruditos são afetados por mudança. Saber identificar o nicho social em que se encontra o padrão funcional já é resposta para a composição do corpus. Então, lidar com descrição linguística pressupõe, como o encaminhamento desta pesquisa demonstrou, saber que nichos sociais e sequências tipológicas de textos podem favorecer o estudo de uma gramática dinâmica. 


\section{BIBLIOGRAFIA}

\section{REFERÊNCIAS BIBLIOGRÁFICAS}

AUlETE, Caldas. Dicionário de Caldas Aulete, $2^{\mathrm{a}}$ edição em 05 volumes. Rio de Janeiro: Editora Delta, 1964

BECHARA, Evanildo. Moderna Gramática Portuguesa, 37 edição revista e ampliada, RJ, Editora Lucerda, 1999.

BIDERMAN, Maria Tereza. Dicionário Contemporâneo de Português, Petrópolis: Vozes, 1992.

BORBA, Francisco da Silva. Dicionário Brasileiro da Língua Portuguesa, $17^{\text {a }}$ edição, São Paulo: Editora Melhoramentos, 2000.

BUENO, Francisco da Silveira. Grande dicionário etimológico-prosódico da Língua

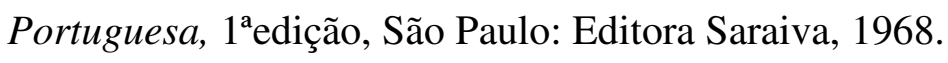

CAMPBELL, L,JANDA, R. 'Introduction. Conception of Grammaticalization and their problems'. In. Language Science. Department of Linguistics, University of Canterbury, Christchurch, New Zealand \& Departmento fo Lingusitics. The Ohio State University, Columbus, Ohio: Pergamon:2001 (pp93-112)

CASTILHO, Ataliba T. (2003). Para publicação em Jânia Ramos e Mônica Alckmim (Orgs. 2003) - Para a História do Português Brasileiro, vol. VI. -Análise multissêmica das preposições do eixo transversal no Português Brasileiro: Espaço/ Anterior/ Posterior

CASTILHO, Ataliba T. de (USP CNPq*). Abordagem da Língua como um Sistema Complexo - Contribuições para uma nova Linguística. (inédito). 
COUTINHO, Ismael de Lima - Pontos de Gramática Histórica,6 $6^{\mathrm{a}}$ edição, Rio de Janeiro, Livraria Acadêmica, 1970.

CRAIG, Colette G. 1991. Ways to go in Rama: a case study in polygrammaticalization. In Approaches to Grammaticalization, TRAUGOTT, Elizabeth Closs and HEINE, Bernard (eds.).

CUNHA, Celso, CINTRA, Luís F. Lindley, Nova Gramática do Português Contemporâneo, $3^{\mathrm{a}}$ edição, RJ, Nova Fronteira, 2001

DAVIES, MARK AND MICHAEL FERREIRA. (2006-) Corpus do Português (45 milhões de palavras, sécs. XIV-XX). Disponível em http://www.corpusdoportugues.org.

DEFENDI, Cristina Lopomo. A reduplicação no português culto falado em São Paulo: possível gramaticalização? Dissertação de Mestrado. SP. 2008.

FARACO, Carlos Emílio; MOURA, Francisco Marto de. Gramática. São Paulo: Ática, 1992. (sem série definida)

FERREIRA, Aurélio Buarque de Holanda, Mini Aurélio Século XXI Escolar: O minidicionário da Língua Portuguesa, 4 edição, Rio de Janeiro, Nova Fronteira, 2001.

FERREIRA, Aurélio Buarque de Holanda, Novo Aurélio Século XXI: O dicionário da Língua Portuguesa, $3^{\text {a }}$ edição, Rio de Janeiro, Nova Fronteira, 1999

FREIRE, Laudelino, Grande e Novíssimo Dicionário da Língua Portuguesa, Volume 1, $3^{\text {a }}$ edição. Rio de Janeiro: A Noite, 1957.

GONÇALVES, Sebastião Carlos Leite. Gramaticalização, modalidade epistêmica e evidencialidade: um estudo de caso no português do Brasil. Tese de doutoramento. Campinas: IEL/UNICAMP, 2003.

GONÇALVES, Sebastião Carlos Leite; LIMA-HERNANDES, Maria Célia \& CASSEB-GALVÃO, Vânia Cristina. Introdução à Gramaticalização: princípios teóricos e aplicação. São Paulo: Parábola Editorial, 2007. 
HEINE, Bernd et alii. Grammaticalization: a Conceptual Framework. Chicago: The University of Chicago Press, 1991.

HOPPER, P. \& E. TRAUGOTT. Grammaticalization. Cambridge: Cambridge University Press, 1993.

HOPPER, Paul J. On some principles of grammaticization. In: Traugott e Heine (ed) Approaches to grammaticalization. Vol I. Focus on theoretical and methodological issues, Amsterdam: Benjamins, 1991.

HOUAISS, Antonio, Dicionário Houaiss da Língua Portuguesa, $1^{\mathrm{a}}$ edição, Objetiva, 2001.

LIMA-HERNANDES, Maria Célia. A interface Sociolinguística/Gramaticalização Estratificação de usos de tipo, feito, igual e como - sincronia e diacronia. Tese de doutoramento. Campinas: IEL/UNICAMP, 2005.

. Esquecimento Histórico e Mudança Linguística: risco de vida no PB. In: LIMA-HERNANDES, M.C.; MARÇALO, M.J.; MICHELETTI, G.; MARTIN, V.L.R. (orgs.) A língua portuguesa no mundo - I Simelp. São Paulo: FFLCH, 2009.

MAIA, João Domingues. Português (ensino médio). São Paulo: Ática, 2002.

MAROTE, João Teodoro D’Olim. Português funcional. São Paulo: Cia. Editora Nacional, 1972 (volume 2 - 6a série).

MARTELOTTA, Mário Eduardo et alii. (1996). Gramaticalização no português do Brasil: uma abordagem funcional. Rio de Janeiro: Tempo Brasileiro.

MOLLICA, Maria Cecília (org.) - CLA Cadernos Didáticos UFRJ - Introdução À Sociolinguística Variacionista. $3^{\mathrm{a}}$ edição, 1996

NASCENTES, Antenor, Dicionário Etimológica Resumido, Instituto Nacional do Livro, MEC, 1966. 
NEVES, Maria Helena de Moura, Gramática de usos do português - $3^{\mathrm{a}}$ reimpressão, São Paulo: Editora UNESP, 2000.

NEVES, Maria Helena de Moura. A gramática funcional. São Paulo: Martins Fontes, 1997.

RISSO, Mercedes Sanfelice, SILVA, Giselle Machline de Oliveira e Silva \& URBANO, Hudinilson. Traços definidores dos marcadores discursivos in JUBRAN, Cléia Cândida Abreu Spinardi \& KOCH, Ingedore Grunfeld Villaça (orgs.). Campinas, SP: Editora da Unicamp: 2006

SARTIN, Elisângela Baptista de Godoy, Gramaticalização orações para mais infinitivo no Português do Brasil. Dissertação de Mestrado. SP. 2008.

SILVA, Antonio de Morais, Dicionário da Língua Portuguesa, 10ª Edição Revista, Corrigida Muito Aumentada e Actualizada, Vol 1, S.l. Editorial Confluência, 1948.

SPAZIANI, Lídia, A gramaticalização do item fora no Português do Brasil: a unidirecionalidade do processo. Dissertação de Mestrado. SP. 2008.

SWEETSER, Eve 1988. 'Grammaticalization and semantic bleaching'. Proceedings of the 14th Annual Meeting of the BLS. Berkeley, CA: Berkeley Linguistics Soc., 389-405.

SWEETSER, Eve 1991. From Etimology to Pragmatics. Cambridge: University Press.

TARALLO, F (org.). Corpus Diacrônico do Português. Campinas, 1991. (documentos xerocopiados)

TRAVAGLIA, Luiz Carlos 2004. A (poli)gramaticalização do verbo acabar. Letras \& Letras, Uberlândia, 21-56.

\section{REFERÊNCIAS BIBLIOGRÁFICAS DA INTERNET}

http://redacaoescola.blogspot.com/2008/02/afinalao-final-ante-oante-ao-subscrever.html 
http://www.kplus.com.br/materia.asp?co=79\&rv=Gramatica

http://www.ieb.usp.br/topico.asp?categ=1\&subcateg=1\&topico=105

http://www.bibvirt.futuro.usp.br/textos/biografias/autores/camilo_castelo_branco

http://www.noticiaki.com/2008/08/assista-ao-vivo-final-entre-brasil-e.html. 